\title{
Komiteen for Erhvervelse af Dybbøl Skanser 1922-1924
}

En iscenesættelse af et dansk erindringssted

\author{
af LARS H. BAK
}

I 1922 opkøbte Komiteen for Erhvervelse af Dybbøl Skanser via en privat landsindsamling otte af de i alt ti tidligere danske skansearealer på Dybbøl Banke. Skansernes beliggenhed blev markeret på arealerne, der samtidig blev fredet mod bebyggelse. Derfor henligger arealerne $i$ dag stort set, som da komiteen i 1924 overdrog dem til den danske stat som en nationalpark til minde om Genforeningen i 1920. Lars H. Bak fortæller i artiklen her om komiteen og landsindsamlingen, der var et privat initiativ, hvor enhver dansksindet blev opfordret til for $\mathbf{1} \mathrm{kr}$. at støtte opkøbet af de danske skanser på Dybbol Banke og dermed sikre dem som et dansk erindringssted.

De danske erindringer om krigen i 1864 var erindringer om nederlaget, der førte til den danske helstats reduktion til en småstat, og til at de dansksindede nordslesvigere mod deres vilje måtte leve under tysk herredømme indtil 1920. De danske erindringer stod i modsætning til de tyske erindringer om krigen som en sejr, der hidtil havde domineret iscenesættelsen af Dybbøl Banke. Komiteens indsamling ligner da umiddelbart en enig dansk nations værk vendt mod områdets præg af tyske erindringers iscenesættelse. Et iscenesat nationalt erindringssted forstået som en fysisk markering af, at en nation til et givent sted knytter bestemte erindringer, foregiver således ofte at være nationens kollektive værk.

Imidlertid var erindringerne om krigen i 1864 heller ikke internt $i$ den danske nation entydige $i$ henseende til dens konsekvenser for eftertiden. I militære og nationalsindede borgerlige kredse blev krigen set som et eksempel på det ærefulde $i$ at forsvare sig mod en overlegen fjende og dermed som et argument for et militært forsvar, mens radikale kredse brugte nederlaget som et argument for det nyttesløse $i$ et dansk militært forsvar. I den socialdemokratiske arbejderbevægelse blev krigen endda opfattet som de borgerliges forførelse af arbejderklassen. I lyset af disse internt konkurrerende danske erin- 
dringer var skansekomiteen måske alligevel ikke en enig dansk nations iscenesættelse af Dybbøl Banke som et dansk erindringssted.

Derfor søges der i artiklen her svar på hvorledes og hvorfor skanserne på Dybbøl Banke blev iscenesat som et dansk erindringssted af Komiteen for Erhvervelse af Dybbøl Skanser 1922-1924 samt hvem og hvad der satte dagsordenen herfor.

Efter 2. Verdenskrig var krigen i 1864 ikke længere altoverskyggende i dansk erindring. Derfor ligner den iscenesættelse af Dybbøl Banke som et dansk erindringssted, som Komiteen for Erhvervelse af Dybbøl Skanser foretog, i dag en enig dansk nations værk, men var komiteens opkøb af skanserne nu også det?

\section{Erindringsstedet Dybbøl Banke}

Dybbøl Banke viste sig under Treårskrigen 1848-50 velegnet som en flankestilling, hvorfor der i 1861 blev anlagt en feltbefæstning tværs over banken fra syd til nord med ti mindre skanser. ${ }^{1}$ Stillingen blev i krigen 1864 besat af den danske hær efter tilbagetoget fra Dannevirke den 6.-8. februar, mens Sundeved blev besat af stadigt mere talmæssigt overlegne preussiske tropper. ${ }^{2}$ Den 18. april 1864 blev stillingen angrebet af de preussiske styrker, der efter 3-4 timers kamp trængte de danske tropper tilbage til Als, som preusserne indtog ved et nyt angreb den 29 . juni. ${ }^{3}$

Efter krigen anlagde preusserne fæstningen Festung SonderburgDüppel, og selvom den blev nedlagt i 1885, forblev Dybbøl Banke domineret af dens skanser. Fæstningens skanse $X$ lå på bankens højeste punkt nord for landevejen til Flensborg, hvor de danske skanser 5 og 6 havde ligget. Her blev den danske genforeningsfest den 11. juli 1920 afholdt med 50.000 deltagere med kong Christian X i spidsen, og lige siden er skansen blevet kaldt Kongeskansen. ${ }^{4}$

Det usædvanlige ved Dybbøl Banke er, at kampene her er blevet holdt $\mathrm{i}$ erindring med fredninger, mindesten og årlige mindehøjtideligheder for slaget den 18. april 1864 etc., som jævnligt har vakt opmærksomhed og debat helt frem til i dag modsat erindringerne om svenskekrigene og englandskrigene. Et særligt behov for at holde krigen i 1864 i erindring her synes da at have gjort sig gældende.

Vi kan klarlægge betydningen af at holde krigen i 1864 i erindring, hvis vi betragter Dybbøl Banke som et erindringssted, der bruges til at opbevare en eller flere erindringer, som anses for truet i eftertiden. ${ }^{5}$ 
Dybbøl Banke var i 1864 en slagmark for både den danske og den tyske nation, men hvor kampene var et klart nederlag for den danske nation, var de for den tyske nation en velforberedt militær sejr. I Tyskland symboliserede Dybbøl Banke derfor indledningen til samlingen af Det tyske Kejserrige i 1871. I Danmark symboliserede Dybbøl Banke derimod nationens store militære nederlag og helstatens endegyldige reduktion til en småstat, hvorfor en afgrænsning mod Tyskland blev en vigtig del af dansk nationalisme efter $1864 .^{6}$

Dybbøl Banke symboliserede således dansk forsvarsvilje og tapperhed overfor en overmægtig fjende. ${ }^{7}$ For de dansksindede slesvigere betød nederlaget i 1864, at de måtte leve under tysk herredømme, hvilket kulminerede med deres tvungne deltagelse i 1. Verdenskrig på tysk side. Dybbøl symboliserede da også en ukuelig danskhed og dens lange kamp for sin eksistens under det tyske herredømme, som efter en folkeafstemning endte med Nordslesvigs genforening med Danmark i 1920, mens Sydslesvig forblev tysk, da en afstemning her havde vist et tysk flertal. ${ }^{8}$

Ud fra denne asymmetri mellem dansk og tysk erindring om kampene på Dybbøl i 1864 kunne skansekomiteens iscenesættelse af området som et dansk erindringssted alene tolkes som en samlet dansk afgræsning mod Tyskland. Men også internt i en nation kan forskellige internt konkurrerende erindringer true hinanden. I den danske hær blev krigen erindret som et eksempel på, hvordan det gik, hvis der ikke blev anvendt tilstrækkelige ressourcer på militæret. ${ }^{9}$ Nationens eksistens og sammenhold blev koblet sammen med militær forsvarsvilje i hærens erindring om sit eget nederlag, hvilket også lå bag støtten til et dansk militært forsvar i konservative kredse og i de mere nationalsindede dele af partiet Venstre. ${ }^{10}$

Omvendt var nederlaget i 1864 for de radikale dele af Venstre, som i 1905 dannede partiet Det Radikale Venstre, et bevis på, at et militært forsvar var nyttesløst og farligt for et lille land som Danmark. Løsningen var i stedet at undgå konfrontation med Tyskland ved en forsigtig udenrigspolitik og ved at samle nationen i et kulturelt fællesskab af frie og oplyste borgere, som giorde den i stand til at overleve, selv hvis landet blev besat. ${ }^{11}$ I den socialistiske og internationalistiske danske arbejderbevægelse blev derimod selve nationalismen opfattet som årsag til nederlaget. Krigen i 1864 var overklassens værk, som arbejderne var blevet lokket til at deltage $\mathbf{i}$ med den af overklassen opfundne nationalisme. ${ }^{12}$ 
Der var altså frem til $1920 \mathrm{i}$ den danske nation nok enighed om, at Dybbøl Banke var en slagmark, hvor nationen led et afgørende nederlag i 1864. Men forskellige politiske og sociale grupper drog forskellige konsekvenser af nederlaget. Også internt i den danske nation herskede der konkurrerende erindringer om krigen.

En iscenesættelse af et erindringssted er dog også betinget af en række praktiske omstændigheder. Når en dansk iscenesættelse af Dybbøl først satte ind efter 1920, hang det i høj grad sammen med ophøret af det tyske herredømme i Nordslesvig, som før da havde hindret større danske markeringer i området. På 50-årsdagen i 1914 for slaget på Dybbøl den 18. april havde en kreds af dansksindede opsat en mindeplade med islændingen pastor Thomassons vers Tvende Gange skudt $i$ Grus på Dybbøl Mølle. Pladen provokerede dog den lokale politimyndighed, amtsforstander Kjer, som fik den taget ned. ${ }^{13}$ Skal en national, politisk eller social gruppe iscenesætte et erindringssted, kræver det altså for det første, at den ikke formelt og fysisk forhindres adgang til området af andre grupper.

For det andet må hele nationen have kendskab til, at iscenesættelsen finder sted, idet alle dens indbyggere enten skal kunne billige eller deltage i den, for at der kan være tale om et udtryk for en samlet nations iscenesættelse. Det forudsætter for det tredje, at hele nationen har praktisk adgang hertil. Det vil i skansekomiteens tilfælde sige praktisk mulighed for at aflevere et bidrag til indsamlingen, hvilket igen forudsætter, at alle nationens indbyggere har et økonomisk overskud hertil.

Endvidere lå Dybbøl Banke kun $2 \mathrm{~km}$ fra Sønderborg ad hovedlandevejen Sønderborg-Flensborg. Den danske hær blev først tvunget helt ud af Slesvig ved preussernes overgang til Als den 29. juni 1864 ved Arnkilsøre, som lå $6 \mathrm{~km}$ fra Sønderborg, men her førte ingen hovedveje hen, og området blev ikke iscenesat som erindringssted i samme grad som Dybbøl Banke. ${ }^{14}$ Iscenesættelse af et geografisk område som erindringssted er altså også et spørgsmål om praktisk adgang til stedet.

\section{Fredninger som iscenesættelse}

Dybbøl Bankes naboskab til købstaden Sønderborg rummede dog også en potentiel trussel mod områdets brug som erindringssted. Som andre byer i vækst krævede Sønderborg et større areal, og her var Dybbøl Bankes østlige del en mulighed. Allerede i 1874 blev en del af gården Langbrogaards jorder, der grænsede op til byen, indlemmet 
i Sønderborg købstad, og efter 1900 voksede en bydel frem her. ${ }^{15}$ Moderne naturfredning opstod netop i kølvandet på 1800-tallets industrialisering og urbanisering. ${ }^{16}$ Komiteen kunne da mere ligne et værn imod skæmmende byggeri.

Den første danske naturfredningslov fra 1917 hjemlede fredninger af områder, »[...] som paa grund af deres skønhed eller ejendommelighed har væsentlig betydning for almenheden og [...] hvis bevarelse af naturvidenskabelige eller historiske hensyn er af væsentlig interesse «. ${ }^{17}$ Et område kunne altså fredes efter loven, hvis det grundet fortidige forhold havde en betydning for nationen i nutiden, som burde opbevares for eftertiden. En fredning i kraft af naturfredningsloven forhindrede ikke nødvendigvis iscenesættelse af konkurrerende erindringer, men bevarede blot muligheden for generelt at iscenesætte erindringer $\mathrm{i}$ området.

En fredning kunne imidlertid også ske ved, at en ejer af et område selv pålagde det servitut om at henligge $i$ en bestemt tilstand, som Komiteen for Erhvervelse af Dybbøl Skanser gjorde. Der var da principielt intet til hinder for, at ejeren på forhånd indrettede sit område, så det direkte fysisk udtrykte en bestemt erindring. Der var da heller ikke tale om et ufrivilligt indgreb i den private brugs- og ejendomsret, som en fredning efter naturfredningsloven var. ${ }^{18}$

Men ved en fredning efter naturfredningsloven forelå et juridisk mandat til at frede og iscenesætte på vegne af nationen. Det var ikke tilfældet ved en privat fredning. Her måtte nationens opbakning først skabes eller konstateres, hvis det skulle have udseende af en national iscenesættelse. Begge typer fredning kunne iscenesætte et område som erindringssted ved at bevare det $i$ en bestemt tilstand. Bemærkelsesværdigt er det da, at Komiteen for Erhvervelse af Dybbøl Skanser opstod i 1922, selvom der allerede i 1920 i medfør af naturfredningsloven var rejst en sag om fredning af Dybbøl Banke. ${ }^{19}$ Var der da behov for en ny dansk iscenesættelse, når det tyske herredømme var væk, og det offentlige ville værne området mod bebyggelse?

\section{Dybbøl Banke anno 1922}

Ved Genforeningen i 1920 var der ikke mange synlige levn tilbage fra kampene på Dybbøl Banke. Allerede i maj 1864 udjævnede den preussiske hær delvist de danske skanser og sprængte deres krudtmagasiner af beton i luften. Ved anlægget af Festung Sonderburg- 


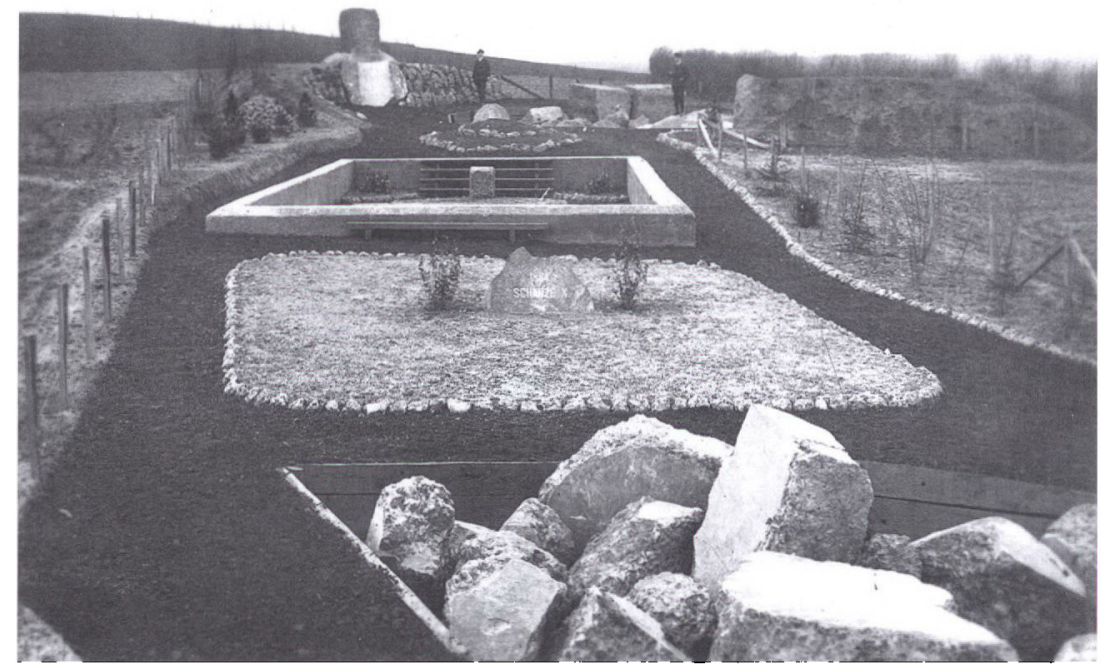

Skanse 10 efter udgravningerne i 1914. Arealet var mindre end den oprindelige skanse 10 og de skansearealer, som skansekomiteen opkobte og markerede. Til gengald havde arealet mere karakter af et anlag. I forgrunden ses resterne af et krudtmagasin, $i$ midten blokhusfundamentet og $i$ baggrunden en mindesten for den preussiske overgang til Als den 29. juni 1864. Skanse 10 var formelt ejet af den tyske varftsejer Kolbe $i$ Kiel, og forst $i 1945$ lykkedes det at erhverve skansen, hoorefter dens beliggenhed blev markeret pi samme maide, som de øorige danske skanser pa Dybbol Banke var blevet det 1922-1924. Foto: Museum Sonderjylland - Sonderborg Slot.

Düppel blev skanserne 3, 5, 6 og 9 helt opslugt af de nye tyske skanser, der efter fæstningens nedlæggelse i 1885 blev solgt til lokale landmænd til afgræsning, mens de øvrige danske skansetomter blev inddraget i markerne. Kun konturerne af voldgraven i skanse 8 og enkelte krudtmagasinrester forblev synlige. Dog havde hjemstavnsmuseet i Sønderborg i 1914 udgravet magasinresterne og blokhusfundamentet $^{20}$ i skanse 10, som tilhørte værftsejer Chr. Kolbe i Kiel. ${ }^{21}$

Den eneste synliggjorte danske skanse i 1920 var altså i privat tysk eje, og i øvrigt var Dybbøl Banke domineret af de skanser, som de preussiske sejrherrer havde opført efter 1864 for at befæste herredømmet i Nordslesvig. Resterne af de danske og tyske skanser vidnede dog i sig selv kun om, at Dybbøl Banke havde haft militær betydning, men ikke om hvilke krigshandlinger der var foregået her.

I terrænet og på kirkegårdene i Sundeved lå en række krigergrave med faldne soldater fra krigen i 1864. På gravene angav tyske gravsten eller kors, at her lå danske eller preussiske faldne og hvornår de var 
faldet. Det danske krigsministerium fik 1909-14 erstattet de tyske trækors på de danske grave med danske gravsten. ${ }^{22}$ I samme område var der ved Genforeningen 13 tyske mindesten, mens det danske krigsministerium 1909-14 havde fået rejst tre mindesten for danske faldne. ${ }^{23}$

Krigergravene og de fleste mindesten gjorde i sig selv kun opmærksom på, at en eller flere her var omkommet under kamp i 1864, men deres hhv. tyske og danske sprog antydede, at både den danske og den tyske nation havde erindringer knyttet til området. Hvem der tabte eller vandt kampene blev før 1920 først synligt ved kransenedlæggelserne under de tyske mindehøjtideligheder for slaget den 18. april 1864 ved krigergravene og dansksindedes ditto i stilhed ved de danske grave. ${ }^{24}$

Derimod var det 24 meter høje sejrsmonument Düppel Denkmal, som den preussiske stat rejste i 1872 i den danske skanse 4, en klar iscenesæettelse af tyske erindringer om krigen i 1864 som en sejr. ${ }^{25}$ Efter 1900 skød enkelte villaer op langs landevejen, og i 1907 blev udsigten fra Düppel Denkmal truet af en udstykning til villaer og et hotel i hhv. øst og nord. En privat komite foranledigede da, at den preussiske stat overtog arealerne rundt om monumentet, og nedlagde forbud mod skæmmende byggeri. Den første fredning på Dybbøl Banke skete altså for at bevare en tysk iscenesættelse i skanse 4, der som den eneste skanse overgik til den danske stat i 1920 sammen med de tyske krigergrave og mindesten. ${ }^{26}$

Ca. 300 meter øst for Düppel Denkmal lå den danskejede Dybbøl Mølle, der var blevet et uofficielt monument for en ukuelig danskhed i Nordslesvig. Udadtil var det dog blot en vindmølle. Ville forbipasserende før 1920 vide noget om danske erindringer, måtte de bese mindesamlingen fra 1904 indenfor i møllehuset. ${ }^{27}$

Da Dybbøl Banke atter kom under dansk herredømme i 1920, var området klart præget af de foregående 56 års tyske herredømme, men med Genforeningen i 1920 forsvandt den umiddelbare trussel mod de danske erindringer, som det tyske herredømme havde udgjort. Til gengæld blev det muligt at iscenesætte de danske erindringer åbenlyst og fjerne tyske levn.

\section{Sejrsmonumentet der blev stående}

I januar 1920 forsøgte den preussiske stat forgæves i strid med Versailles-traktaten at overdrage Düppel Denkmal til foreningen 
»Düppel-Arnkiel «. ${ }^{28}$ Den 14. juni 1920 anmodede den tyske gesandt i København den danske regering om alligevel at anerkende overdragelsen, men den danske regering foreslog da, at monumenterne blev udvekslet med det danske monument for Treårskrigen, Istedløven. Det svarede den tyske regering aldrig officielt på, og da det ikke lykkedes den danske regering at få udvekslingen taget op til forhandling, lod den fra 1922 monumenterne forfalde.

Den klare iscenesættelse af tyske erindringer, som Düppel Denkmal var, ragede altså fortsat op på Dybbøl Banke, da skansekomiteen foretog sin indsamling i 1922. Den danske stats ønske om at få Düppel og Arnkiel Denkmal fjernet bekræfter, at de to sejrsmonumenter stod i modsætning til de danske erindringer om 1864. Omvendt viser forsøgene fra tysk side på at sikre Düppel Denkmals forbliven på Dybbøl Banke, at det nye danske herredømme her blev opfattet som en trussel mod de tyske erindringer. Begge nationer havde fortsat et behov efter 1920 for at opbevare erindringer på Dybbøl Banke, som de gensidigt genererede hos hinanden.

Hverken det tyske mindretal i Nordslesvig eller den tyske stat havde anerkendt 1920-grænsen. Det diplomatiske forslag om udveksling med Istedløven var et udslag af, at den danske stat generelt ønskede at undgå politisk og national uro i Nordslesvig i forhold til det danske flertal, såvel som til det tyske mindretal og den tyske stat. Realpolitiske hensyn satte da grænser for, hvilke indgreb staten kunne foretage overfor de eksisterende tyske iscenesættelser, selvom de truede danske erindringer. Klager over monumenternes forfald fra tysk side førte til, at staten istandsatte Düppel og Arnkiel Denkmal mådeligt i hhv. 1926 og 1927. Men da havde Dybbøl Banke efterhånden også fået et dansk præg. ${ }^{29}$ Allerede inden skansekomiteens oprettelse i 1922 havde enkelte aktører været i gang. Var der her tale om konkurrerende danske erindringer?

\section{Atter vajer Dannebrog}

I 1919 blev pladen med Thordur Thomassons vers atter sat op på Dybbøl Mølle, og den danske besættelsesstyrke i Nordslesvig, Sønderjydsk Kommando, rejste efter sin ankomst i maj 1920 en mindesten i skanse 2 for dens danske forsvarere, mens familien til den i 1864 faldne oberst Lasson satte en mindesten sydøst for møllen. ${ }^{30}$

Klarest blev det nye danske herredømme markeret i 1920, da Dan- 
ske Soldaterforeningers Fællesudvalg overtog Dybbøl Mølle og vest for denne rejste en 25 meter høj flagmast med tilladelse til at bære splitflag. Her blev Dannebrog hejst første gang ved genforeningsfesten den 11. juli, men ellers flagedes kun på søn- og helligdage samt de officielle flagdage, indtil flagningen blev gjort daglig i november 1940. Med splitflaget, som ellers var forbeholdt statslige institutioner, fik flagningen dog et officielt skær. Den danske nations genvundne herredømme på Dybbøl Banke blev således markeret fra dag ét. ${ }^{31}$ Men det var ikke ensbetydende med, at der i den danske nation nu kun var knyttet én bestemt dansk erindring til Dybbøl Banke.

Det viste sig året efter, da Sønderjydsk Kommando den 18. april 1921 afholdt den første danske mindehøjtidelighed på Dybbøl Banke for slaget i 1864. Her udtalte garnisonschefen, oberst Moltke, at: "for første gang lyder her den 18. april fædrelandets tak på denne måde til folkets tapre sønner, som kæmpede her og sammen med modstanderne indviede denne jord med deres blod. « $^{32}$ Efterfølgende var der gudstjeneste bag Dybbøl Mølle, hvor pastor Peter Hansen bl.a. sagde i sin tale: "Du har et fædreland at dø for. Det har vore tapre forsvarere vist os. « ${ }^{33}$ Ved den første danske mindehøjtidelighed fremstillede den danske hær altså sit nederlag i 1864 som et takskyldigt forsvar for nationen, som fortsat var værd at efterligne.

En stik modsat erindring kom til udtryk, da Socialdemokratiet i Sønderborg og Augustenborg kredsene den 5. juni 1921 afholdt grundlovsmøde på Dybbøl Banke. Til tonerne af Internationale gik deltagerne med røde faner, men uden Dannebrog, til Kongeskansen. Her sagde den lokale folketingsmand J.P. Nielsen i sin åbning af mødet, at: "vi er dog dem, der har mest ret til pladsen. Det var sønner fra de små hjem, der vædede landet her med deres blod « ${ }^{34}$, mens landstingsmand C.F. Sørensen mente om soldaterne i 1864, at "de troede at kæmpe for fædrelandet, men nu har man fået øjnene op for, at det kun var kapital-interesser, der stod bag ved det hele." Til slut mente partiformand Thorvald Stauning, at Dybbøl »[...] minder om slagsbrodermoral, der intet har med folkenes selvbestemmelsesret at gøre. « 35

Socialdemokraterne gav her udtryk for en antimilitaristisk erindring, hvor kamp mod en overmagt ikke var værdifuldt, men spild af liv og blod. Det var folkenes selvbestemmelsesret med Genforeningen, som nu sikrede den danske nations eksistens. Ikke et håbløst militært forsvar. Derfor gik socialdemokraterne på Dybbøl Banke på Grundlovsdag den 5. juni og ikke på Dybbøldagen den 18. april. 
Selvom Genforeningen i 1920 havde givet oprejsning for nederlaget i 1864, herskede der altså fortsat konkurrerende erindringer internt $\mathrm{i}$ den danske nation. De kunne nu hver især iscenesættes på Dybbøl Banke. Men bortset fra nogle efterhånden visne kranse og lidt nedtrampet græs efterlod hverken grundlovsmødet eller mindehøjtidelighederne permanente fysiske spor i området, som kunne videregive de iscenesatte erindringer til folk, der ikke havde overværet dem eller havde kendskab til dem. De kunne heller ikke forhindre iscenesættelse af hinanden eller andre internt konkurrerende danske erindringer, lige så lidt som iscenesættelse af eksterne tyske erindringer på Dybbøl Banke, der stadig lå åbent for byggeri.

\section{En fredning efter loven}

Faren for skæmmende byggeri blev allerede taget op den 9. juli 1920, da Fællesudvalget for Landsfredning foreslog en fredning af Dybbøl Banke i videst muligt omfang inklusiv de danske og tyske skanser mod bebyggelse og beplantning, da »[...] det vil være unødvendigt til støtte for dette andragende at anføre hvilken enestående betydning alene navnet Dybbøl har for enhver dansk og for fædrelandet [...] «. ${ }^{36}$ I sin kendelse den 7. marts 1922 ville Fredningsnævnet for Sønderborg Amtsraadskreds dog kun frede den vestlige del af Langbrogaard, Snedgaard vest og syd for denne samt et areal langs landevejen således, at det kun måtte bebygges med fredningsnævnets tilladelse $\mathrm{i}$ hvert enkelt tilfælde, "da det af landskabelige og historiske grunde skønnes af betydning for almenheden, at de i sagen omhandlede arealer af Dybbøl Bjerg fredes [...] «. ${ }^{37}$ Fællesudvalget ankede dog afgørelsen til Overfredningsnævnet, ${ }^{38}$ som i sin kendelse af 28 . juni 1923 fredede de arealer syd for landevejen, som lå nord for sognevejen fra Fællesgravene eller øst for de nu af Komiteen for Erhvervelse af Dybbøl Skanser ejede arealer til nær Sønderborg. De af Fredningsnævnet for Sønderborg Amtsraadskreds' kendelse omfattede arealer samt den nordlige del af gårdene Langdamsgaard og Grønkær måtte kun bebygges med de for landbrug nødvendige bygninger, mens villaer på op til otte meters højde var tilladt på det øvrige areal, da bebyggelse af de sydøstligste dele "under hensyn til Dybbøl Bankes ganske særlige betydning i national og historisk henseende $[. .$.$] « ville virke skæmmende. { }^{39}$

Fredningen i 1923 var altså alene et værn imod skæmmende byggeri, som ikke ændrede på områdets præg af tyske iscenesættelser eller 
forhindrede nye iscenesættelser af konkurrerende danske eller tyske erindringer. Den bevarede alene muligheden for i det hele taget at iscenesætte erindringer på Dybbøl Banke.

\section{Komiteen for Erhvervelse af Dybbøl Skanser oprettes}

Komiteen for Erhvervelse af Dybbel Skansers indsamling var langt fra den eneste indsamling i disse år til dansk arbejde i Sønderjylland. Størst var indsamlingen til Den sønderjydske Fond, som især støttede nødlidende sønderjyske veteraner fra 1 . Verdenskrig samt deres familier og efterladte. Den indbragte fra januar 1919 til oktober $1921 \mathrm{i}$ alt $6.530 .129,04 \mathrm{kr}^{40}$

Det var netop blandt personer fra Den sønderjydske Fond, at skansekomiteen havde sit ophav. Berlingske Tidendes chefredaktør Chr. Gulmann og Carlsbergs direktør Vagn Jacobsen, medlem af hhv. fondens bestyrelse og centralkomite, foreslog den 14. juni 1921 et tredje medlem af centralkomiteen, statsminister Niels Neergaard, at rejse et mindesmærke for Genforeningen i Kongeskansen. Via retsfuldmægtig J. H. Miang i Sønderborg fik de tre herrer oplyst, at skansen var i tysk eje. ${ }^{41}$ Foranlediget af Chr. Gulmann forsøgte amtmand Lundbye i Sønderborg da at købe Kongeskansen. Det endte med, at ejeren af slotsmøllen i Sønderborg, Thomas Berthelsen, købte skansen pr. 1. november 1921 for $28.000 \mathrm{kr}$., som han fik fra initiativtagerne til mindesmærket. Berthelsen selv var kun stråmand. ${ }^{42}$ De tyske ejere måtte altså ikke få nys om planerne om et dansk genforeningsmindesmærke.

I oktober 1921 kontaktede kongehusets advokat, Otto Liebe, fondens kontorchef, Anders Charles Louw, om et eventuelt køb af den tysk ejede gård, på hvis jorder skanse 1 og 2 havde ligget, og som en anden tysker nu ville købe. ${ }^{43}$ Amtmand Lundbye oplyste, at det var et tysk konsortium med tidligere amtsforstander Kjer, som ville købe gården for at bruge arealet syd for Düppel Denkmal til en sportsplads. ${ }^{44}$ Amtmanden må være blevet bemyndiget til at købe gården, for den 27 . december meddelte han, at gården, hvor en del af skanse 3 også hørte med, ville blive købt samme dag med en udbetaling pr. 1. januar til ejeren, E. Lauterlein, på 75-80.000 kr. ${ }^{45}$ Via bestyrelsesformand for Den sønderjydske Fond professor Edv. Ehlers lånte initiativtagerne 80.000 kr. af fonden til gårdens køb. Chr. Gulmann oplyste da, at det nu også var planen at købe skanse 9 og at overdrage skanserne til Statsministeriet. $^{46}$ 
Hvorvidt der reelt forelå en tysk trussel om at købe Lauterleins gård, eller om ejeren søgte at presse prisen op, kan ikke afgøres ud fra kildematerialet, men oplysningerne udløste det danske opkøb. Det gjaldt nu ikke kun om at rejse et dansk monument, men også om at undgå nye tyske aktiviteter på Dybbøl.

Personkredsen bag opkøbene, der også talte fondens initiativtager kirkeminister J. C. Christensen og centralkomitemedlemmerne redaktør Harald Witzansky, dagbladet København, og redaktør Andreas Buntzen, Nationaltidende, sikrede sig i begyndelsen af januar 1922 tillige arealerne, hvorpå resten af skanse 3 samt 7,8 og 9 havde ligget. En del af den tyske skanse IX, hvor den danske skanse 9 havde ligget, blev dog først købt i efteråret 1922 grundet uenighed med den danske ejer om prisen, mens tyske Chr. Kolbe uvist hvorfor ikke ville sælge skanse $10 .{ }^{47} \mathrm{I}$ alt opkøbte initiativtagerne ca. 60,2 ha på Dybbøl Banke for $244.854,15 \mathrm{kr}^{48}$ Ifølge en senere udtalelse af Vagn Jacobsen frabad kong Christian $X$ sig dog et særligt monument og mente i stedet, at udlægning af skanserne til folkepark ville være det værdigste mindesmærke for Genforeningen og danske faldne i de slesvigske krige. ${ }^{49}$

Initiativtagerne knyttede altså en dansk erindring til skansearealerne om Genforeningen i 1920 som en oprejsning for nederlaget i 1864, og de opkøbte derfor skanserne, fordi et truende tysk ejerskab af arealerne kunne hindre et dansk mindesmærke og føre til nye tyske iscenesættelser. Selvom der var flere ministre, rigsdags- og embedsmænd blandt initiativtagerne, skulle den danske stat formelt først inddrages $\mathrm{i}$ iscenesættelsen af skanserne, når den fik overdraget skanserne. Opkøbet af de danske skansearealer på Dybbøl Banke var altså en iscenesættelse af et dansk erindringssted i privat regi, men hvorfor det, når der allerede var rejst en offentlig fredningssag i medfør af naturfredningsloven?

\section{Invitation til iscenesættelse}

Hidtil havde det ikke været et problem at skaffe de nødvendige penge fra private donationer og lån, og det synes at fremgå af uklare notater fra initiativtagernes møde den 23. januar 1922, at de havde yderligere godt 100.000 kr. på hånden. Men Chr. Gulmann og Niels Neergaard foretrak en offentlig indsamling, som hele folket kunne delagtiggøres $i$. Neergaard bifaldt da et forslag fra Harald Witzansky om en kroneindsamling via dagspressen, så 200.000 mennesker hver kunne bidrage 
med $1 \mathrm{kr}$. Mødedeltagerne blev enige om, at indsamlingen skulle begynde den 10 . februar og slutte den 18 . april $1922 .{ }^{50}$ Den primære grund til landsindsamlingen var altså ikke pengenød, men derimod at skanseopkøbene skulle være en iscenesættelse med hele den danske nations medvirken, og det skulle 200.000 bidragydere være et udtryk for.

Initiativtagerne udarbejdede et opråb, hvori det indledningsvis hed: "De skanser, hvor Danmark skrev Genforeningens løftebrev med sine sønners blod, ligger endnu på Dybbelbjerg, og der var det, kongen og sønderjyderne gav hinanden håndslag. Besiddelsesforholdene medførte fare for, at dele af disse skanser kunde få en anvendelse, der var lidet stemmende med det danske folks ønsker om at bevare den historiske grund som et samlet hele og give den en værdig og varig plads i vort folks liv.« Støttet af en offentlig indsamling ville en kreds af mænd derfor overgive skanserne til staten som en folkepark $i$ uforandret tilstand bortset fra nogle forbindelsesveje. Det danske folk ville da opfylde sin pligt til at sætte Genforeningen et mindesmærke, der vidnede om »[...] vore fædres udholdende kamp kronet med sejr og deres håb med fuldbyrdelse.« Da det danske folk netop skulle sætte mindesmærket samlet, iværksatte kredsen en kroneindsamling, der »[...] vil gøre vore landsmænd i titusinder til andelshavere i Dybbøl Skanser [...] «, og som skulle begynde den 10 . februar, toårsdagen for afstemningen $\mathrm{i}$ Nordslesvig $\mathrm{i}$ 1920 og slutte på Dybbøldagen den 18. april 1922. ${ }^{51}$

For den her udtrykte danske erindring var de tyske erindringer om krigen i 1864 som en sejr en trussel, men udkastet synes også at være vendt imod andre danske erindringer. Ikke mindst socialdemokraternes erindring om det nyttesløse militære forsvar, som kom til udtryk på grundlovsmødet i 1921. Alligevel opfattede initiativtagerne deres egen erindring som kollektiv for hele den danske nation.

\section{Komiteen stiftes}

Initiativtagerne udsendte opråbet med en invitation til et møde den 6. februar 1922 på Christiansborg til inklusiv dem selv i alt 98 mænd og fem kvinder. ${ }^{52}$ Hvor mange der kom til mødet vides ikke. Der var en del afbud, mens 44 indbudte på forhånd tilsluttede sig opråbet. ${ }^{53}$ På mødet fandt J.P. Nielsen en indsamling overflødig, når der verserede en fredningssag, men ifølge J.C. Christensen ville en offentlig fredning ikke hindre, at ejerne brugte området til møder og lejre. J.P. Nielsen replicerede, at jævnfør naturfredningsloven bestemte staten, 


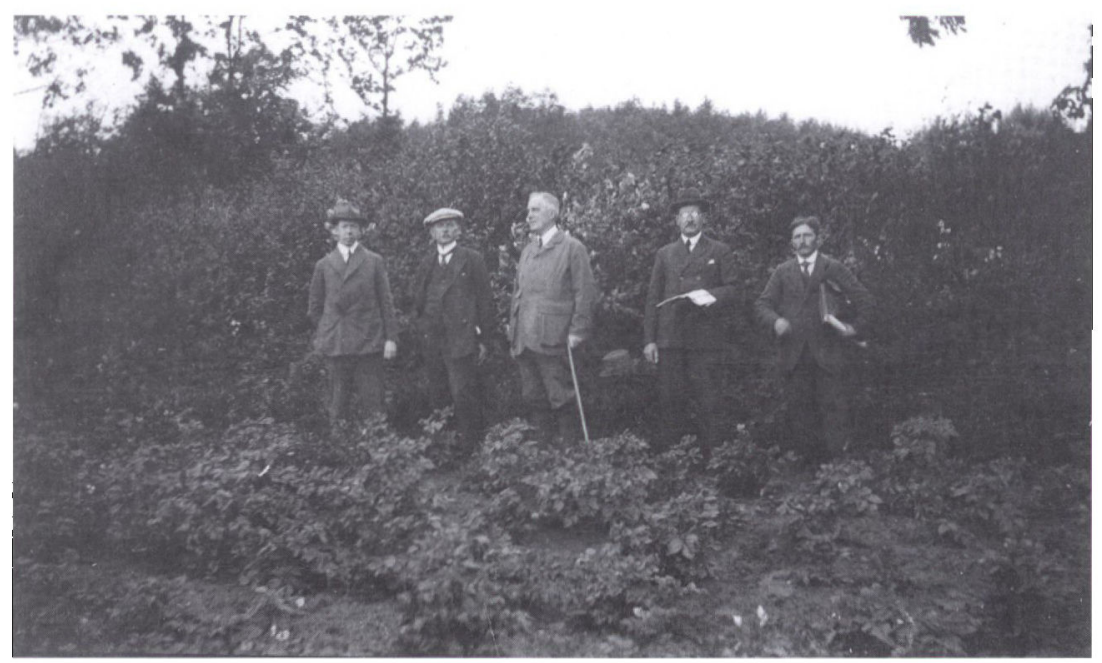

I juli 1922 foretog komitemedlemmerne Vagn Jacobsen, Chr. Gulmann, kontorchef Louw og professor Edv. Ehlers en inspektionsrejse til Dybbol Banke sammen med ingeniørkaptajn T. J. Helsted, som bistod komiteen med afmærkningen af skansernes beliggenhed. Den samlede delegation ses pai billedet, som formentlig er taget $i$ haven ved Lauterleins gård, i dag Skansegaarden. Foto: Museum Senderjylland ISL-Lokalhistorie.

hvad de fredede arealer måtte bruges til. Han kunne støtte, at staten overtog området, men det mente J.C. Christensen ikke var det samme som en indsamling, som hele folket deltog i. ${ }^{54}$

Det var altså ikke den erindring, som ophavsmændene ville iscenesætte på Dybbøl Banke som hele nationens, som J.P. Nielsen anfægtede, men derimod deres iscenesættelsesform. J. C. Christensens modargumenter overfor J.P. Nielsen viser, at ophavsmændene opkøbte skanserne trods den igangværende fredningssag fordi de ikke fandt, at en statslig fredning kunne forhindre tyske opkøb og iscenesættelser, endsige iscenesætte Dybbøl Banke som et dansk erindringssted i tilstrækkelig grad.

På samme tid var J.C. Christensen som kirkeminister sammen med blandt andre statsminister Niels Neergaard med til at grundlægge den officielle politik om, at der efter afstemningerne i 1920 ikke eksisterede noget spørgsmål om den dansk-tyske grænse, som skiftende danske regeringer forte gennem hele mellemkrigstiden. Som konsekvens heraf tog den danske stat hensyn til de nationale forhold $\mathrm{i}$ Nordslesvig og førte en pragmatisk politik overfor det tyske mindretal og Tyskland for at undgå uro. ${ }^{55}$ Denne politik gav sig som nævnt 
udslag i den danske stats håndtering af Düppel Denkmal, og et indgreb overfor nye tyske iscenesættelser på Dybbøl eller statsopkøb af skansearealerne ville da karambolere med den pragmatiske politik.

Derimod var et privat opkøb ikke i strid med denne politik. Initiativtagerne benyttede sig jo blot af den frie private ejendomsret, som gjaldt for både det danske flertal og det tyske mindretal i Nordslesvig. Derfor var der større spillerum for danske iscenesættelser af Dybbøl Banke i privat regi end i statsligt. Nok var den første danske mindehøjtidelighed i 1921 for slaget den 18. april 1864 arrangeret af staten ved den lokale garnison, men den efterlod ikke permanente fysiske spor. Derimod gav soldaterforeningernes flagbastion og pladen på møllen området et dansk præg i privat regi. Da formålet med skansernes opkøb og fredning netop var at iscenesætte dem som et dansk erindringssted overfor konkurrerende tyske erindringers iscenesættelse, blev det ligeledes foretaget i privat regi.

Efter forslag af den radikale landstingsmand Hermann Trier blev opråbets indledende sætning uden debat ændret til, at »skanserne paa Dybbøl bjerg er for det danske folk blevet et udtryk for den lange udholdende kamp, der har ført til Sønderjyllands genforening med Danmark « ${ }^{56}$ Forstået ordret udtalte opråbet nu intet om, hvorvidt det militære forsvar i 1864 havde været nødvendigt eller ej. Samtidig stod alle danske erindringer i modsætning til de tyske erindringer om krigen i 1864 som en sejr, der, som opråbet antydede, kunne blive iscenesat på Dybbøl. Opråbet var altså henvendt til hele den danske nation på tværs af politiske og sociale skel og ikke ment som en iscenesættelse af en bestemt dansk erindring på bekostning af andre internt konkurrerende danske erindringer.

Det færdige opråb blev støttet af 82 indbudte, som dermed stiftede Komiteen for Erhvervelse af Dybbøl Skanser. Vagn Jacobsen var formand og kasserer og Chr. Gulmann sekretær. Mindst 58 af de 82 havde i forvejen forskellig tilknytning til Nordslesvig. Af 57 medlemmer fra hovedstadsområdet havde de 37 nordslesvigske præferencer, ligesom seks af de ni medlemmer fra det øvrige Danmark, mens 16 boede i Nordslesvig. Af politikere var der 16 venstrefolk, fem konservative og to radikale, mens ingen af fem indbudte socialdemokrater tilsluttede sig komiteen. Det samme gjaldt de redaktører, som tilsluttede sig opråbet, hvor to kom fra venstreblade, fire fra konservative aviser og en enkelt, Kristian Dahl, fra en radikal avis. Generelt indtog medlemmerne socialt højtrangerende erhverv. Der var ingen håndværker- 
svende og arbejdere, mens gårdejerne $\mathrm{i}$ komiteen alle varetog et politisk hverv. ${ }^{57}$

Med den totale mangel på repræsentanter fra den socialdemokratiske arbejderbevægelse og de lavere sociale lag i samfundet samt den borgerlige dominans udgjorde den endelige komite ikke et repræsentativt udsnit af den danske nation. Overvægten af medlemmer fra hovedstadsområdet og Nordslesvig udgjorde også en afvigelse i forhold til den danske befolkning generelt. Ikke desto mindre ville den private komite legitimere sit opkøb af skanserne som hele den danske nations iscenesættelse af skanserne på Dybbøl Banke som dansk erindringssted med en landsindsamling. Spørgsmålet er nu, hvorvidt det lykkedes.

\section{En national indsamling?}

Det er ikke muligt ud fra Komiteen for Erhvervelse af Dybbøl Skansers arkiv eller andre kilder at klarlægge præcis hvem og hvor mange, der via kroneindsamlingen støttede opkøbet af skanserne. Men på baggrund af pressens omtale af indsamlingen og de tiltag, som komiteen foretog for at fremme den, er det muligt at give et kvalitativt svar på, hvor vidt indsamlingen var en enig dansk nations iscenesættelse af skanserne på Dybbøl Banke som et dansk erindringssted.

Efter mødet den 6. februar 1922 forestod Vagn Jacobsen, kontorchef Louw, Chr. Gulmann og Ejner Guildal som komiteens arbejdsudvalg indsamlingen, der således var styret af få personer. ${ }^{58}$ Udvalget udsendte opråbet til pressen med anmodning om at bringe det den 10 . februar og at modtage læsernes bidrag. ${ }^{59}$

I 1922 var dagspressen det altdominerende daglige nyhedsmedie $\mathbf{i}$ Danmark, hvor der udkom i alt 301 avistitler. ${ }^{60}$ Dagspressen var da et uundgåeligt medie for at gøre nationen bekendt med indsamlingen, men nyheden herom kunne blive fremstillet på 301 forskellige måder, hvis aviserne da skrev om den. Når komiteen bad om at få et bestemt opråb offentliggjort på en bestemt dato, var det vel for at få nyheden om indsamlingen gengivet $\mathrm{i}$ samme version på samme tid til hele den danske nation.

\section{Komiteens presse}

Ud fra komiteens arkiv kan der sammenstykkes et kvantitativt overblik over de aviser, der modtog bidrag. ${ }^{61}$ I alt 135 aviser indsamlede 
bidrag på deres redaktioner, og i de fleste købstæder modtog to redaktioner bidrag, men også lokalaviser i en række stationsbyer samlede ind. Fraregnes Island, Grønland og Færøerne, omfattede indsamlingen i pressen altså hele den danske nation geografisk set.

Anderledes så det ud med avisernes partitilhørsforhold, hvor der var en klar borgerlig tendens. Af de 135 aviser var hele 57 venstreblade, 57 konservative, seks radikale, mens seks var af forskellig uafhængig borgerlig observans. Endvidere var der fem upolitiske aviser, fire avisers partitilhørsforhold har ikke kunnet identificeres, og ikke én eneste socialdemokratisk avis deltog $i$ indsamlingen. Konservative og venstreaviser udgjorde i starten af $1920^{\prime}$ erne ca. $48 \%$ af det samlede oplag, mens de radikale blade havde $17 \%$ og A-pressen $14 \%{ }^{62}$ Tages der højde for, at enkelte radikale og uafhængige blade samlede ind, ser det ud til, at der blev opfordret til at bidrage til indsamlingen i ca. halvdelen af de aviser, der udkom i Danmark i 1922.

En gennemgang af en række udvalgte avisers omtale af indsamlingen i perioden fra den 7. februar til den 18. april 1922 viser, at der også var stor forskel på, hvordan de enkelte aviser omtalte indsamlingen alt efter deres politiske orientering. ${ }^{63}$

Konservative aviser som Berlingske Tidende og Nationaltidende i København og Fyns Stiftstidende i Odense offentliggjorde opråbet den 10. februar og gav samtidig og i de følgende dage indsamlingen varme anbefalinger, så nationen kunne bevare erindringen om det tapre og nødvendige forsvar i 1864. Således skrev Fyns Stiftstidende den 10. februar, at »[...] tanken om at bevare skanseresterne paa dette sted uforandrede frem gennem tiderne vil af nationalt sindede danske kvinder og mænd blive følt som en hellig pligt - først og fremmest mod de uforfærdede og trofaste brødre, der satte livet ind for folk og fædreland. " ${ }^{64}$

Venstreaviser som Fyns Tidende i Odense og Dybbøl-Posten i Sønderborg samt en liberal avis som Hejmdal i Aabenraa støttede også indsamlingen fra starten. Efterfølgende bragte aviserne enkelte opfordringer til at bidrage til opkøbet af skanserne for derved at bevare erindringen om forsvaret i 1864, som var nødvendigt for at den danske nation kunne overleve. Dybbøl-Posten kaldte den 10. februar Dybbøl Banke for "[...] symbolet på viljen til selvhævdelse [...]«.65 Samme dag fandt Fyns Tidende det naturligt at frede Dybbøl Banke så "[...] den kan tale også til efterslægten om, at her stred et lille folk for sit liv, og at trods al modgang stred det ikke forgæves. «66 Især de nordslesvigske blade ivrede dog for indsamlingen. Jævnligt bragte Dybbøl-Posten således indsam- 


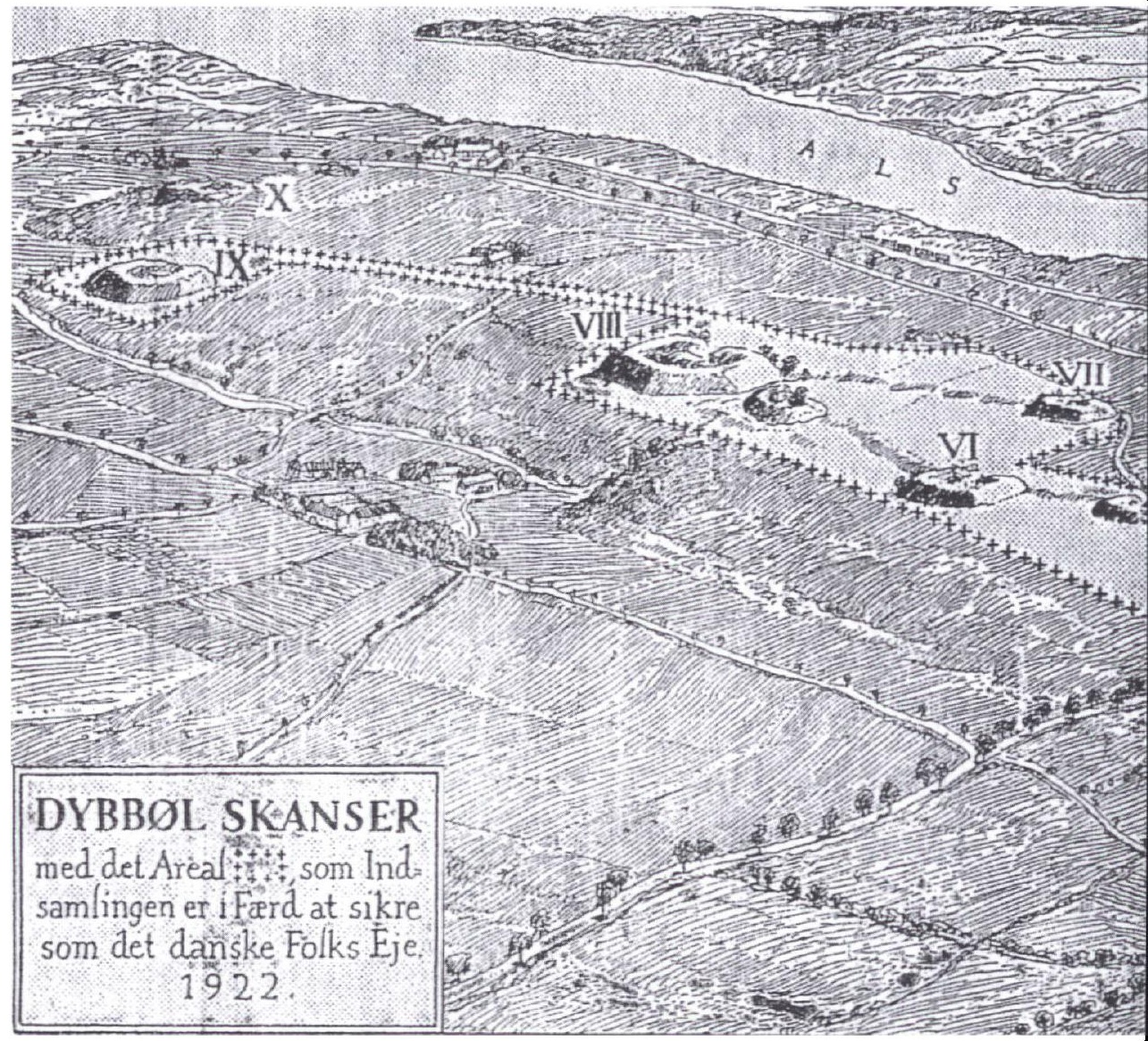

Skansekomiteens reliefkort, tegnet af H.V. Westergaard. De af komiteen erhvervede arealer er de lyse fremhazoninger. Kortet viser de forsoundne danske skanser, men ikke de stadig eksisterende preussiske skanser. Af tyske leon ses kun Düppel Denkmal. Kortet fremstillede sailedes Dybbol Banke som et dansk erindringssted uden at tage stilling til, om det danske forsvar i 1864 var arefuldt eller unødvendigt. Hensigten var tydeligvis at samle den danske nation på tværs af politiske og sociale skel om indsamlingen til kobet af skanserne. Foto: Landsarkizet for Sonderjylland.

lingslister og små opfordringer som "giv afkald på en lille nydelse og skænk 1 krone til Dybbøl-indsamlingen. ${ }^{67}$

Også radikale blade som Politiken i København og Fyns Venstreblad i Odense anbefalede ved starten indsamlingen, men modsat konservative aviser og venstreaviser var det småt med efterfølgende opfordringer til at give bidrag. Fyns Venstreblad bragte hverken opråbet 


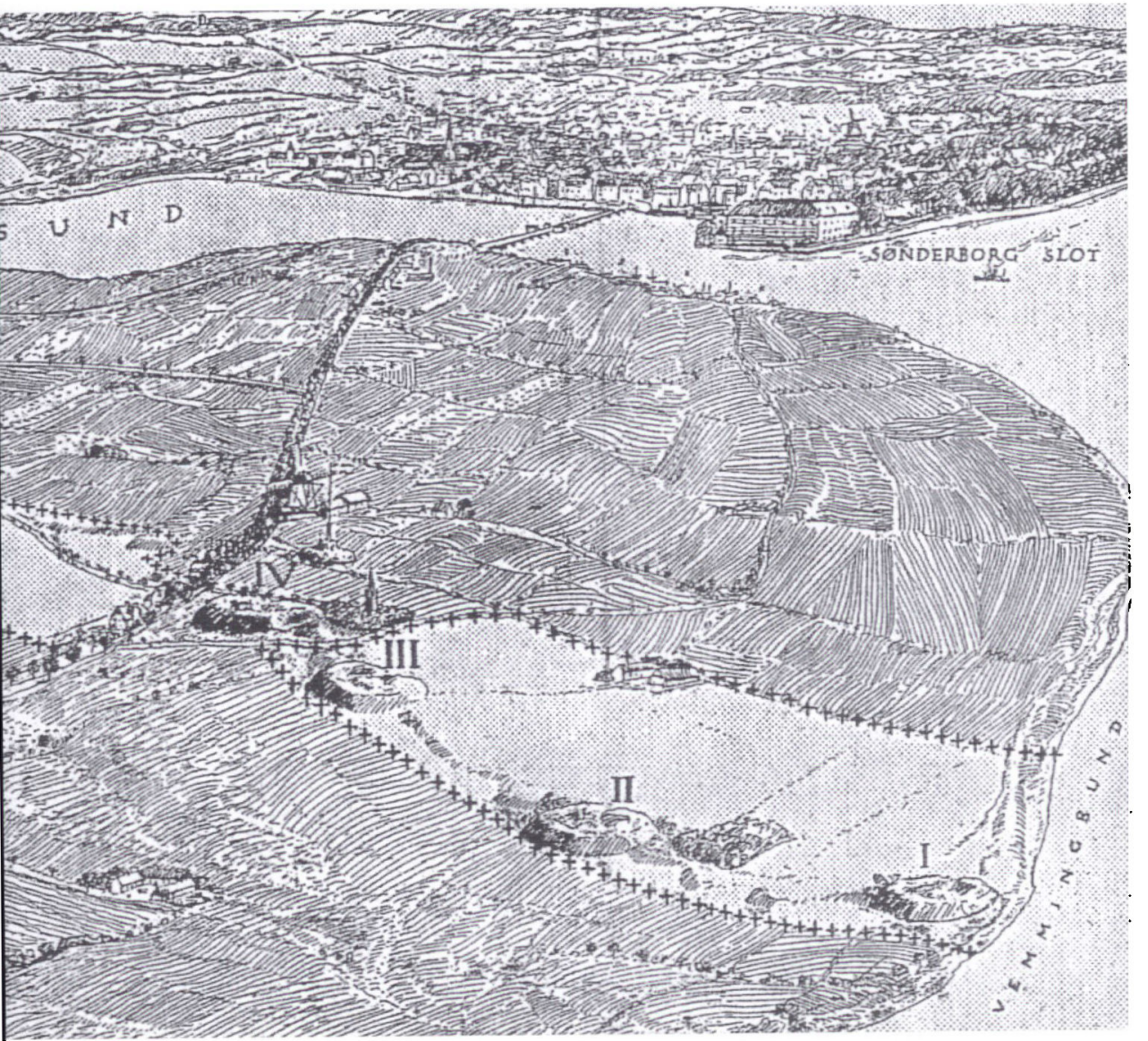

eller modtog bidrag, men alligevel anbefalede bladet to gange at støtte indsamlingen. Den 1. april blev Dybbøl dels kaldt »[...] vidnesbyrdet om en forbryderisk-tåbelig politik [...] « og dels mindet om de danske soldaters "[...] lidelser, deres seje udholdenhed og jævne heltemod.« Derfor var Dybbøl "[...] både et tegn til advarsel og et tegn til efterfølgelse. ${ }^{68}$ Fyns Venstreblad erindrede her de danske soldaters forsvar i 1864 som tappert, men modsat venstre- og konservative aviser anså radikalerbladet dette forsvar mod overmagten for unødvendigt. Dybbøl Banke manede ikke til militært forsvar, men advarede tværtom imod militarisme. Politiken var derimod påfaldende neutral med hensyn til hvilken erindring om det militære forsvars nytte den 
danske nation burde knytte til skanserne, men gav dog indtryk af, at indsamlingen mødte opbakning i hele Danmark..$^{69}$

Direkte kritik mødte komiteens indsamling kun i den socialdemokratiske presse. Arbejderbevægelsens moderavis i København, SocialDemokraten, fandt i sin eneste omtale af indsamlingen den 10. februar, at pengene til købet af skanserne var bedre givet ud til veteraner og invalider fra krigen. ${ }^{70}$ Fyns Social-Demokrat i Odense og Sønderborg Amts Social-Demokrat i Sønderborg omtalte kun yderst kortfattet indsamlingen ved dens start. Derudover kaldte begge blade i enslydende artikler, som formentlig da også er blevet bragt $\mathrm{i}$ andre socialdemokratiske aviser, den 21. marts opkøbet af skanserne og indsamlingen hertil for en gang »nationalt rummel«, som var overflødigt, når nu staten var i gang med at frede området. ${ }^{71}$

Derimod kritiserede Sønderborgs gamle tyske blad, Sonderburger Zeitung, ikke indsamlingen. Bladet omtalte den 8 . februar mødet i Rigsdagen om indsamlingen, men nævnte ellers kun indsamlingen, da Vagn Jacobsen den 9. april havde ytret utilfredshed med indsamlingens hidtidige resultat. ${ }^{72}$ Det tyder på, at der fra den tysksindede nordslesvigske presses side ikke kunne findes angrebspunkter mod denne iscenesættelse i privat regi af Dybbøl Banke som dansk erindringssted.

Samlet set lykkedes det altså kun for komiteen at få ca. halvdelen af de danske aviser til at samle ind til eller støtte opkøbet af skansearealerne. Konservative aviser og venstreblade anbefalede varmt deres læsere at stotte indsamlingen, så erindringen om de danske soldaters tapre og nødvendige forsvar mod overmagten i 1864 kunne bevares. Radikale kunne også støtte indsamlingen, men det skete enten i mere neutrale vendinger eller ud fra en erindring om et unødvendigt militært forsvar i 1864 . Socialdemokratiske aviser frarådede derimod indsamlingen, men det var fordi den blev anset for overflødig med den igangværende fredningssag og ikke nødvendigvis fordi, at A-pressen knyttede en anden erindring til skanserne på Dybbøl end komiteen og de borgerlige blade. Hele nationen blev via pressen oplyst om indsamlingen, men det var vidt forskelligt, hvordan den enkelte avis omtalte den.

\section{Kommitteret pr-arbejde}

Med de godt to måneder, som indsamlingen strakte sig over, var nyhedsværdien af dens iværksættelse ikke nok, hvis nationen vedvaren- 
de via pressen skulle mindes om indsamlingen og give indtryk af en samlet national iscenesættelse. Den 10. februar udsendte arbejdsudvalget en pressemeddelelse til hovedstadsbladene, som gav indtryk af, at indsamlingen var kommet godt fra start, idet komiteen allerede havde modtaget den første 100 kroneseddel før udsendelsen af opråbet. ${ }^{73}$ Senere udsendte udvalget en kliche til pressen med et reliefkort over Dybbøl Banke tegnet af H.V. Westergaard, som 61 aviser takkede ja til at bringe. ${ }^{74}$

Imidlertid herskede der allerede på udvalgets møde den 13. februar en opfattelse af, at indsamlingen var kommet uheldigt fra start i pressen. Ifølge redaktør Kristian Dahl, Politiken, var indsamlingen ramt både af storlockouten, som skulle iværksættes dagen efter og af den herskende isvinter. ${ }^{75}$ Til brug for pressen anmodede Vagn Jacobsen den 25 . februar 30 af komiteens medlemmer om at afgive en skriftlig udtalelse, hvilket 15 indvilligede i. ${ }^{76}$

Generelt i udtalelserne blev skanserne på Dybbøl fremhævet som hellig jord for alle danske, som derfor havde pligt til at bevare dem. Flere beklagede, at indsamlingen gik trægt, men kirkeminister J.C. Christensen mente dog, at det blot gjaldt om at få indsamlingen praktisk ordnet. Han pegede her på lærerstanden, som ofte fortalte børnene om Dybbøl. "Hvis Danmarks lærere og lærerinder vil tage sagen i deres hånd, da er den sikret«, skrev den tidligere lærer.

Gennemgående blev de danske soldaters tapre indsats i 1864 også fremhævet, men betydningen for eftertiden blev betonet lidt forskelligt. Maleren N.V. Dorph skrev, at »Dybbøl er symbolet for vor styrke i afmagten, for sejren i nederlaget «, idet soldaterne her havde sat livet ind på at forsvare den jord, som altid var og altid blev dansk "[...] selv under fremmed åg «. Den radikale landstingsmand Hermann Trier skrev derimod, at indsamlingen ville gøre området til et billede på nationens tak "[...] for den trofaste udholdenhed, med hvilken danske sønderjyder to menneskealdre igennem har ført en aldrig trættet kamp for bevarelsen af deres modersmål og deres tilbagevenden til Danmark «. ${ }^{77}$ Udtalelserne fremhævede altså Dybbøl Banke som symbol for Danmarks vilje til at overleve. Hensigten var at samle nationen, og ikke at splitte den ved at kritisere andre danske erindringer.

Udtalelserne blev i løbet af marts måned udsendt til ca. 75 provinsblade samt enkelte hovedstadsblade. ${ }^{78}$ I det hele taget bestod hovedstadsbladenes omtale af komiteen og indsamlingen $i$ højere grad end provinspressens af selvstændigt udarbejdede eller indhentede artikler 
og kommentarer, mens provinspressen i rigt mål benyttede sig af de af komiteen udsendte pressemeddelelser, udtalelserne og reliefkortet. Berlingske Tidende og Nationaltidende omtalte indsamlingen hhv. $21 \mathrm{og}$ 23 gange i perioden 7. februar-18. april 1922, men kun hhv. seks og fem gange kan det identificeres som omtale på baggrund af materiale udsendt fra komiteen. Dybbol-Posten omtalte indsamlingen 22 gange, men heraf var det 10 tilfælde på basis af materiale fra komiteen. Blandt Fyns Stiftstidendes 17 omtaler var andelen af komiteens materiale endnu højere med hele 12 gange. Fyns Venstreblad, der støttede men ikke deltog $\mathrm{i}$ indsamlingen, bragte derimod kun én pressemeddelelse. ${ }^{79}$

Med pressemeddelelserne, reliefkortet og udtalelserne lykkedes det således for arbejdsudvalget at få de dele af provinspressen, der i forvejen støttede og deltog $\mathrm{i}$ indsamlingen til fortsat at omtale den med vægt på Dybbøl Banke som symbol for nederlaget i 1864 med Genforeningen som oprejsning herfor. Herunder også i de socialdemokratiske provinsaviser, hvis kritik i marts formentlig var udløst af de borgerlige provinsblades fornyede og fortsatte interesse for sagen. Teoretisk set havde hele nationen altså via pressen mulighed for at få kendskab til indsamlingen, men ikke nødvendigvis med den gennemslagskraft og $\mathrm{i}$ den version, som komiteen selv udtrykte med opråbet den 10 . februar 1922. Hverken mødenotater eller andet tyder dog på, at arbejdsudvalget indlod sig på diskussion med sine kritikere, som kunne have udstillet, at den ikke havde opbakning i hele den danske presse og dermed ødelægge billedet af en samlet nations iscenesættelse.

I det hele taget gav komiteens arbejdsudvalg overfor pressen indtryk af, at indsamlingen gik godt. Den 4 . marts hed det i en ny pressemeddelelse, at der til komiteens kasserer og til de københavnske blade nu var indkommet i alt 47.014,33 kr., men at der ikke forelå nogen meddelelser fra indsamlingerne i provinsen. ${ }^{80}$ Endvidere meddelte komiteen den 7. april, at Vagn Jacobsen fra kongeparret havde modtaget $500 \mathrm{kr}$., samt at danskere bosat i Bangkok og Detroit også samlede ind til komiteen, mens nogle danskere i Salerno i Italien ligesom cigareksportør Emil Hiort-Lorenzen på Cuba hver havde sendt et bidrag. ${ }^{81}$

Komiteen foregav her, at indsamlingen omfattede og blev støttet af hele den danske nation. Lige fra kongen til danskere bosat langt udenfor statens grænser. Komiteen fortrængte helt i sit pressemateriale kritikken i de socialdemokratiske aviser, og fremstillede da indsamlingen som en dansk nations iscenesættelse af sin kollektive erindring på tværs af politiske og sociale skel i den venligtsindede presse. 


\section{Penge i banken}

En ting var dog at gøre hele nationen bekendt med indsamlingen. Noget andet var at få indsamlet bidragene. Her havde komiteen lagt op til en betydelig indsats fra bidragyderne selv, idet bidragene jo skulle afleveres på bladenes redaktioner, der oftest lå i købstæderne og de større stationsbyer, mens godt halvdelen af Danmarks 3.268.000 indbyggere boede i sognekommunerne. Selvom sognekommunerne også omfattede forstæder og stationsbyer, ${ }^{82}$ måtte en stor del af befolkningen altså rejse et stykke vej til en redaktion blot for at aflevere én enkelt enkrone.

Allerede i midten af februar fik Ejner Guildal derfor hovedstadsbankerne til at samle ind fra alle deres afdelinger. Endvidere fik arbejdsudvalget 159 banker og sparekasser i provinsen med filialer til at samle ind, hvorved antallet af indsamlingssteder blev øget betragteligt, og landboerne fik nemmere adgang til at afgive et bidrag. ${ }^{83} \mathrm{De}$ indsamlende pengeinstitutter skulle synligt anbringe opråbet og en plakat tegnet af kunstneren Sandstrøm. Plakaten ses ikke i komiteens arkiv, men ifølge Nationaltidende viste den en knælende ung pige, der med Dannebrog som baggrund fremstrakte en skål, hvori nogle mønter faldt. ${ }^{84}$ Via en del af landets pengeinstitutter fik komiteen altså lettet adgangen til at aflevere bidrag og øget reklamen herfor.

\section{Komiteer og sogneråd}

Efter redaktør Kristian Dahls forslag skrev komiteen endvidere den 18. februar til formændene for de 1.113 lokalkomiteer, som i 1919 lokalt havde samlet ind til Den sønderjydske Fond, for at få dem til at iværksætte lokale indsamlinger. Selvom om der her kunne forventes en særlig interesse for sagen og Sønderjylland $\mathrm{i} ø v$ rigt, imødekom kun 293 komiteer anmodningen. Komiteen skrev også til landets ca. 990 sognerådsformænd om at foretage indsamling, hvad kun 82 imødekom. ${ }^{85}$ Heraf var ingen af de deltagende sognerådsformænd eller lokalkomiteer fra Nordslesvig. ${ }^{86}$

I komiteens arkiv findes kun 41 afslag fra sogneråds- og komiteformænd, som dog afslører, at der ikke nødvendigvis lå en erindringsmæssig modsætning eller national ligegyldighed bag den manglende opbakning herfra. Hele 16 afslog med henvisning til, at den lokale presse modtog bidrag til komiteen, mens seks begrundede deres af- 


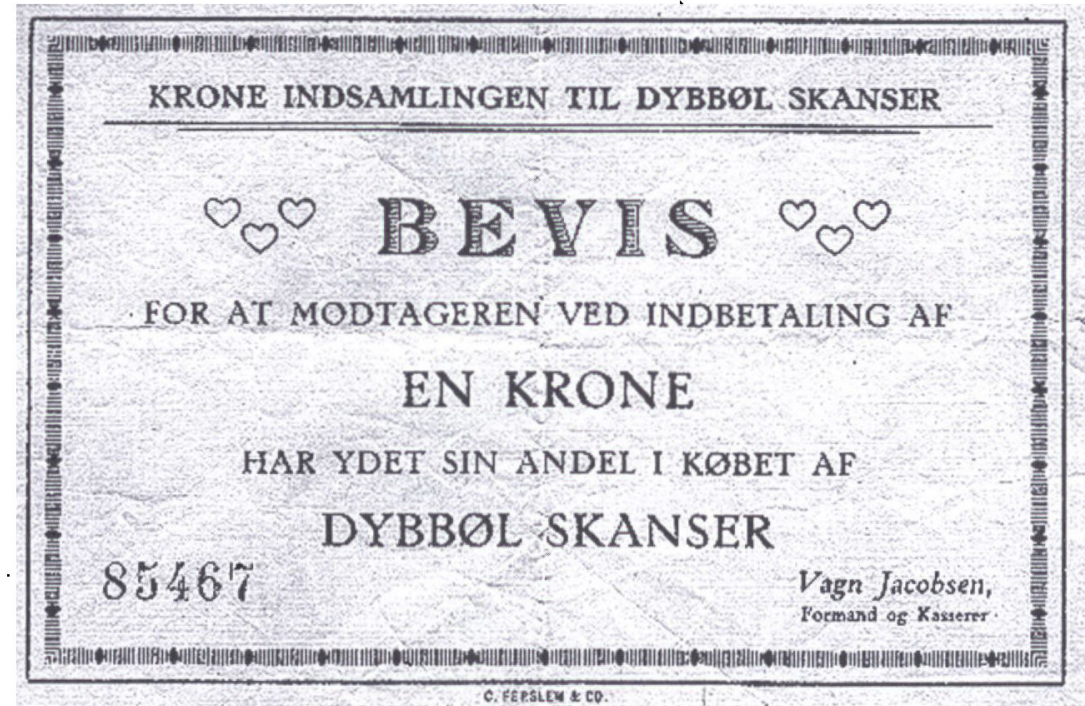

Kvittering for indbetaling af én krone til skansekomiteens indsamling. Kvitteringerne gav indbetalerne et bevis pá at have stottet kobet af de danske skanser. De lettede også indsamlingsstedernes afregning med komiteen, idet de var nummererede og fremstillet $i$ hefter. Alligevel er den viste kvittering den eneste, som findes i komiteens arkiv. Foto: Landsarkivet for Sonderjylland.

slag med, at folk nu var trætte af de sidste års mange indsamlinger. Andre henviste til tidens trange økonomiske kår. Sognefogeden i Starup pr. Tofterup svarede, at »[...] jeg i min bestilling som sognefoged i disse nedgangstider har så stort besvær med at få skatterestancer indkrævede, at det er mig umuligt at komme til nogen skatteyder om frivilligt bidrag i nogen henseende." Afslag grundet uenighed i komiteens opråb ses derimod ikke. ${ }^{87}$

Det er dog vanskeligt ud fra kun 41 afslag at udlede en generel årsag til den manglende opbakning fra ca. 1.800 sognerådsformænd og lokalkomiteer. Afslagene kan blot være et skalkeskjul for, at de adspurgte ikke gad det praktiske arbejde, som en indsamling ville medføre, men de viser dog, at den praktiske opbakning til nationale formål ikke var uden grænser blandt lokale ledere og folk med sønderjysk engagement. Træthed overfor tidens mange indsamlinger synes at have været fremherskende, ligesom tidens trange kår $i$ landbruget kan have genereret en vis påholdenhed. Når kun godt en fjerdedel af de lokalkomiteer, der i 1919 deltog i den succesfulde 
indsamling til Den Sønderjydske Fond og dermed viste interesse for sønderjyske forhold, nu tre år senere ville samle ind til skanserne, tyder det også på træthed overfor det sønderjyske spørgsmål, og at tilslutningen til en iscenesættelse af en erindring også er konjunkturbestemt i økonomisk og praktisk henseende.

Overfor offentligheden fremstillede komiteen de nye indsamlingssteder som en ekstra opbakning til komiteen i nationen. Komiteen skrev blot i pressemeddelelsen af 4 . marts, at nu modtog også samtlige pengeinstitutter i Kobenhavn bidrag tillige med 159 banker og sparekasser i provinsen, mens der var dannet 150 indsamlingskomiteer over hele landet, ligesom 24 foreninger og boghandlere i København samlede ind, så der nu i alt var ca. 800 indsamlingssteder landet over ${ }^{88}$ Komiteen fortrængte her atter, at de nye indsamlingssteder var et udslag af en uventet træg opbakning for at tilpasse billedet udadtil af indsamlingen som en kollektiv dansk nations iscenesættelse. Det er uklart, hvilke foreninger og boghandlere i Kobenhavn, der var tale om, og hvordan indsamlingen her kom i stand, men i komiteens arkiv ses en del uopfordrede indsamlinger. Eksempelvis indsamlede Det Danske Spejderkorps i Kolding ved eget arbejde 26 kr. $^{89}$

For at lette indsamlingsarbejdet havde komiteen fremstillet hæfter med røde enkronebeviser "for at modtageren ved indbetaling af en krone har ydet sin andel i købet af Dybbøl skanser. ${ }^{90}$ Komiteen gav derved bidragyderen et bevis på at være medejer af skanserne og dermed have deltaget $i$ iscenesættelsen af nationens erindringer, hvilket igen viste, at bidragyderen var en del af den danske nation.

\section{Indsamlingen tages i skole}

Som nævnt opfordrede J.C. Christensen i sin udtalelse lærerstanden til at tage hånd om indsamlingen til skanserne. I henvendelsen til landets sognerådsformænd gjorde arbejdsudvalget opmærksom på denne opfordring, og fem sognerådsformænd svarede, at de overlod indsamlingen til kommunens lærere eller at de havde fået hjælp af disse. Endvidere ses af komiteens arkiv, at tre formænd afviste at samle ind, men pegede på J.C. Christensens forslag som en mulighed, ligesom Vedersø og Korup sogneråd afslog, da deres lærere allerede havde samlet ind til skanserne. ${ }^{91}$

J.C. Christensens udtalelse gav også stødet til et udefra kommende initiativ. I Berlingske Tidende den 11. marts 1922 foreslog skolebestyrer- 
inde Marie Mørk i Hillerød, at alle landets skoler sluttede sig sammen om en Dybbølindsamling. Den "opvoksende slægt « måtte inddrages $i$ indsamlingen, og "[...] den er også villig, men trænger til et puf. [...] Vi skal sørge for, at de unge ikke glemmer »det største øjeblik i Danmarks historie.« « Det skete bedst ved, at eleverne samlede ind, og lærerne burde da fortælle eleverne om landskabet på Dybbøl med møllen, skanse 2 og gravene samt genforeningsfesten i 1920. Eleverne behøvede ikke at give en hel enkrone, thi "[...] hver yde, som han evner [...] Lad vore skolebørn, små og store, fattige og rige, få den glæde, at de en gang kan stå med deres børn på Dybbøl festplads og sige: Jeg var med til at sikre os alle dette! « ${ }^{92}$

Marie Mørks forslag blev taget op af komiteen, som omkring den 18. april til alle landets skoler udsendte et opråb, der var identisk med Marie Mørks indlæg i Berlingske Tidende. Dog var der til slut tilføjet, at opråbets underskrivere godt vidste, at der blev stillet mange krav til skolerne, men "[...] vi kommer dog trøstig, fordi vi ved, at denne lejlighed er enestående, aldrig kommer igen. "Skolernes bidrag skulle indsendes inden udgangen af april ifølge opråbet, der var underskrevet af 15 lærere og rektorer. Heriblandt Marie Mørk. ${ }^{93}$

Opråbets opfordring blev fulgt af 221 skoler. Bedømt efter skolernes navne, var der mest tale om offentlige grundskoler, men også en del realskoler og enkelte gymnasier, bl.a. Sorø Akademi, samt nogle privatskoler deltog. Der var typisk tale om landsbyskoler, da kun 35 af skolerne lå i en købstad eller i København. Blot en enkelt skole, Statsskolen i Aabenraa, lå i Nordslesvig. ${ }^{94}$

De fleste indsamlende skoler lå altså på landet, i stationsbyer eller forstæder og dermed i egne, som kunne have langt til en avisredaktion. Via skoleindsamlingen fik komiteen yderligere udbygget nettet af indsamlingssteder og lettet muligheden for at afgive et bidrag. Men indsamlingen nåede på den måde også ud til børn på landet og til børn fra de lavere sociale lag, som ofte ikke kom videre i uddannelsessystemet end til landsbyernes grundskoler. ${ }^{95}$ Også socialt set blev nettet altså udbygget.

De indsamlede beløb var ganske vist afhængige af den enkelte skoles elevtal, idet skolerne på landet, der havde færre elever end skolerne i byerne, ${ }^{96}$ ofte indsamlede under $10 \mathrm{kr}$, mens skolerne i byerne typisk indsamlede $10-50 \mathrm{kr} .{ }^{97}$ Men beløbene var også afhængige af befolkningens sociale sammensætning $\mathrm{i}$ den enkelte skoles distrikt. 
Således skrev skolebestyrer Fr. Range fra Sct. Josephs Skole på Nørrebro i København, at der kun var indsamlet 26,50 kr. på skolen, som var lille og kun blev benyttet af børn af fattige forældre. Andre skoler forklarede det lille beløb eller afslog med, at de lokale aviser og andre allerede havde samlet ind. ${ }^{98}$ Også den enkelte danskers økonomiske formåen spillede ind på opbakningen til komiteen. Ikke alle havde råd til at støtte indsamlingen og de færreste mere end en gang.

Men via skoleindsamlingen fik komiteen atter lettet den praktiske adgang til at aflevere bidrag, og den fik samtidig adgang til et væsentligt nationaliseringsinstrument. Skolen havde via sin undervisning $i$ bl.a. historie siden 1800-tallet haft afgørende betydning for opbygningen af en national identitet. ${ }^{99}$ Hvis lærerne på de indsamlende skoler fulgte opråbet og gav eleverne en lektion om krigen i 1864, Genforeningen og Dybbøl Banke, udbredte de altså en forestilling om en erindring om Genforeningen som oprejsning for nederlaget i 1864 som hele den danske nations erindring, der var knyttet til Dybbøl, hvorfor købet af skanserne var $\mathrm{i}$ alle danskeres interesse, uanset om de selv bidrog til indsamlingen. Denne erindring synes yderligere udbredt ved, at de opvoksende elever formentlig måtte overbevise deres forældre herom for at kunne give et bidrag til indsamlingen. Dermed blev Dybbøl Banke også via indsamlingen i skolerne iscenesat som dansk erindringssted.

\section{Indsamlingen kører på skinner}

Komiteen fik også ekstern hjælp af stationsforstander Stoumann, Knarreborg, som den 10. februar foreslog at opfordre landets stationsforstandere til, ligesom ham selv, at samle ind til skanserne. De fleste stationsforstandere havde før samlet ind, og de ville anse det for en ære at samle ind til skanserne. Komiteen kunne derfor blot tilsende dem en plakat og nogle kvitteringshæfter. ${ }^{100}$

Stoumanns egen indsamling gik imidlertid trægt. Pr. 2. april havde han kun fået indsamlet $10 \mathrm{kr}$. Men i slutningen af marts udsendte han sammen med 15 kolleger et opråb til landets stationsforstandere om at samle ind til skansekomiteen. Det hed her, at der næppe var tvivl om, at mange på landet gerne ville give et bidrag til købet af skanserne, men at det var for besværligt og dyrt at sende bidraget til nærmeste by, hvor indsamlingsstederne i øvrigt var uheldigt placeret. Derimod havde 
mange lejlighed til at aflevere et bidrag på nærmeste jernbanestation. ${ }^{101}$

Af $i$ alt 896 henvendelser modtog Stoumann imidlertid kun 352 svar, hvoraf 279 indvilligede $i$ at samle ind, 15 var tvivlsomme og 58 afslog direkte. De indsamlende stationsforstandere fik tilsendt Sandstrøms indsamlingsplakat samt nogle af de nævnte kvitteringshæfter. Mange forstandere tvivlede dog på, at de kunne indsamle et større beløb, da de lokale aviser og banker eller andre $\mathbf{i}$ forvejen samlede ind til skanserne. Det var også begrundelsen for de fleste afslag. Dog svarede stationsforstanderen i Rinkenæs ved Gråsten, at man her for længst havde samlet småpenge sammen til skanserne, men nu ville ingen give noget, da lønningerne var blevet nedsat. En anden station svarede, at stemningen blandt rangerpersonalet ikke var god, efter at der var indført en 9 timers arbejdsdag. ${ }^{102}$

Stationsforstander Stoumann fik altså ikke overvældende opbakning blandt sine kolleger, ligesom de ikke påtog sig opgaven med den største optimisme. Men såvel de tøvende svar som afslagene viser, at indsamlingen til skanserne nu faktisk var nået ud i alle kroge af Danmark. Oveni blev så tilføjet yderligere mindst 279 nye indsamlingssteder $i$ form af stats- og privatbanestationer. Da jernbanen endnu i starten af 1920 'erne var et dominerende transportmiddel til lands, også på kortere afstande som fra en landsby til nærmeste købstad, ${ }^{103}$ var det altså steder, hvor de fleste danskere formentlig kom langt oftere end på en avisredaktion.

Det ses af de 136 stationer, som efter den 18. april meldte tilbage om resultatet, at det undertiden betød noget. Mens stationen i Odense, hvor to redaktioner og flere banker samlede ind, kun indsendte 6 kr., kunne landstationen Kavslunde ved Middelfart indsende hele 25 kr. I Nordslesvig kunne resultaterne endog være ekstra store. Mens stationen i Gråsten, hvor Graasten Avis i forvejen indsamlede, indsendte $4 \mathrm{kr}$., indsamlede Tørsbøl st. vest for Gråsten hele $40 \mathrm{kr}$. Omvendt solgte hverken Nørrebro st. i Kobenhavn eller Langeskov st. vest for Odense en eneste kvittering. ${ }^{104}$

Resultaterne synes altså mindst blandt stationerne i de større byer, hvor banker og avisredaktioner i forvejen samlede ind og størst ude på landet, hvor der var langt til disse faciliteter. Forskellene på Kavslunde og Langeskovs resultater viser $\mathrm{dog}$, at beløbet kunne svinge fra station til station. Men selvom de rejsende på en indsamlende station ikke gav et bidrag, kunne den ophængte plakat og en evt. opfordring fra stationsforstanderen minde dem om, at hele nationen havde knyt- 
tet en erindring til skanserne på Dybbøl, og at indsamlingen derfor var til alle danskeres gavn. Stationsforstandernes indsamling var da en promovering af Dybbøl Banke som hele den danske nations erindringssted, og den medvirkede derved til, at området via komiteens indsamling blev iscenesat som dansk erindringssted. I den henseende kørte indsamlingen altså i begyndelsen af april 1922 på skinner.

\section{Nationale toner slås an}

Et par begivenheder i København kunne også give indtryk af, at indsamlingen til skanserne gik godt. Den 7. april 1922 afholdt Det kgl. Kapel en koncert i København til fordel for købet af skanserne. I den flagsmykkede udsolgte hal på rådhuset spillede kapellet bl.a. Niels W. Gades 4. symfoni i B-dur. Ind i mellem sang kammersangerne Tenna Frederiksen og Albert Høegberg. Senere spillede kapellet Ernst Hornemanns Fantasi over danske fædrelandssange, bl.a. Dengang jeg drog af sted fra 1848, som under publikums jubel måtte gentages, inden kapellet sluttede med ouverturen til Elverhøj. Denne dansk nationale koncert indbragte med billetpriser på 1-3 kr. komiteen i alt 2.257,84 kr. ${ }^{105}$

Endvidere afholdt rektor og lærebogsforfatter Henrik Madsen, Skt. Jørgens Gymnasium, et lysbilledforedrag i Odd Fellow Palæet i København til fordel for købet af skanserne den 18. april 1922 om danske digteres brug af den danske natur, der var understottet af især billeder fra Sønderjylland. Ifølge Berlingske Tidende var publikum begejstret for foredraget, men dets økonomiske resultat kendes ikke. ${ }^{106}$

Umiddelbart ligner kapellets koncert og Henrik Madsens foredrag tegn på stor opbakning $\mathrm{i}$ hele den danske nation til komiteens arbejde. Reelt var det dog kun det publikum, der overværede de to begivenheder, der her udtrykte denne støtte. Begge arrangementer fandt sted i landets eneste storby København, hvor landets kulturelle elite af embedsmænd, akademikere og handelsborgerskab især boede. ${ }^{107}$ Selv en meget lille del af den store bys indbyggere kunne da nemt fylde en stor sal, mens lignende arrangementer ikke fandt sted i provinsen. Men læserne af avisernes referater af begivenhederne blev delagtiggiort i dem og dermed i indtrykket af, at de var et udtryk for hele nationens opbakning til komiteen og dens indsamling, ligesom de har kunnet bekræfte komiteen $i$, at dens virke nød stor opbakning i nationen.

Heller ikke i denne henseende var alle støttearrangementer dog en succes. Det københavnske herrekor Bel Canto havde i 1919 afholdt en 
koncert til støtte for Den sønderjydske Fond for fulde huse. ${ }^{108}$ I 1922 tilbød koret en koncert til støtte for skansekomiteen. Koncerten blev først afholdt den 3. november 1922 i Odd Fellow Palæet med billetpriser på 1-3 kr. og gav et underskud på 71,99 kr., som Odd Fellow logen, hvor komitemedlemmet Petrus Beyer var storsire, dog betalte. ${ }^{109}$

Efter den egentlige indsamling var afsluttet kunne det altså være svært at samle kontant støtte til skansekomiteen. Koncerten med $\mathrm{Bel}$ Canto var ikke den eneste skuffelse. Komiteen aftalte med Grænseforeningen, hvis formand Fr. Vinding Kruse var medlem af komiteen, at halvdelen af den del af overskuddet på foreningens salg af Dybbølmærker til fordel for det danske mindretal i Sydslesvig i 1922, som oversteg overskuddet i 1921, tilfaldt komiteen. ${ }^{110}$ Men da overskuddet i 1922 kun blev $50.000 \mathrm{kr}$. $\bmod 78.000 \mathrm{kr}$. i $1921,{ }^{111}$ udløste det ikke penge til komiteen. Sammenlignet med Den sønderjyske Fonds indsamling i 1919 var støtten til nationale indsamlinger stilnet af.

I årene 1912-15 havde Komiteen for Nationalmindesmærket for Krigene 1848-50 samt 1864 forsøgt at indsamle penge. Men bl.a. på grund af 1 . Verdenskrigs trængsler mislykkedes denne indsamling. ${ }^{112}$ Et af denne komites medlemmer var skansekomitemedlemmet Harald Witzansky, og på et møde den 20. juni 1922 mellem generaltøjmester Nørresø, Charlotte Norrie og Harald Witzansky fra mindesmærkekomiteen og skansekomiteens arbejdsudvalg blev det besluttet, at skansekomiteen skulle have overladt mindesmærkekomiteens indestående midler på ca. $14.000 \mathrm{kr}$. Pengene skulle især anvendes til markering af de danske skansers beliggenhed og til at gøre dem tilgængelige for offentligheden. ${ }^{113}$

Mindesmærkekomiteens indsamling antyder her sammen med skansekomiteen og indsamlingen til Den sønderjydske Fond, at den kontante støtte til en indsamling til nationale formål var konjunkturbestemt $\mathrm{i}$ to henseender. For det første økonomisk, idet mindesmærkekomiteens og skansekomiteens indsamlinger til dels fandt sted under indtryk af økonomiske trængsler i form af henholdsvis 1. Verdenskrig og faldende priser samt stigende arbejdsløshed, mens landet var præget af et begyndende opsving, da indsamlingen til fonden startede $i$ 1919. For det andet synes opbakningen bestemt af behovet for national iscenesættelse. Mindesmærkekomiteen kunne ikke i 1912-15 drage fordel af en national opblomstring, som fonden kunne omkring Genforeningen 1919-20 og skansekomiteen til dels i 1922. Endvidere synes det konkrete formål afgørende. De to komiteer ville hver sætte et mindes- 
mærke på nationens vegne, mens fondens formål var socialt arbejde, som fik markant højere kontant støtte. Spørgsmålet er da, om komiteen nåede sit mål om 200.000 danskere, der hver gav en enkrone?

\section{Pengene i kassen}

På et møde i komiteen den 7. juli gav Vagn Jacobsen en foreløbig oversigt over komiteens indtægter. Gennem hovedstadspressen var der indsamlet $35.909,86 \mathrm{kr}$. og via provinspressen $30.155,12 \mathrm{kr}$. Hertil kom i alt 70.287,49 kr., som var indsamlet gennem banker og sparekasser, sognerådsformændene og formændene for Den sønderjydske Fonds lokalkomiteer samt forskellige boghandlere og foreninger. Stationsforstandernes indsamling havde indbragt $4.445,90 \mathrm{kr}$. og skoleindsamlingen havde givet $5.181,14 \mathrm{kr}$. I alt havde indsamlingen indbragt $145.982,51 \mathrm{kr}^{114}$

Komiteen havde altså ikke opnået, at 200.000 danskere hver afgav en enkrone. Oveni kom dog i alt 58.589,67 kr. i forskellige enkeltbidrag fra bl.a. danskere bosat i udlandet og Det kgl. Kapels koncert, ligesom en anonym person alene havde givet $20.000 \mathrm{kr}$. Dertil havde mindesmærkekomiteen overdraget skansekomiteen 14.211,10 kr. Komiteen for Erhvervelse af Dybbøl Skanser havde altså indsamlet $i$ alt $218.783,28 \mathrm{kr}$. Til købene af skansearealerne var der til amtmand Lundbye oversendt 204.500 kr., hvorunder lånet på 80.000 kr. fra Den sønderjydske Fond var tilbagebetalt, og til administration var der brugt 8.552,17 kr. Tilbage havde komiteen pr. 7. juli 1922 altså 5.731,11 kr. til sit videre arbejde. ${ }^{115}$

Vagn Jacobsen mente, at den førnævnte økonomiske afmatning og urolighederne på arbejdsmarkedet havde præget indsamlingen, hvorfor komiteen havde oprettet de mange ekstra indsamlingssteder for at opretholde princippet om en enkroneindsamling. Vagn Jacobsen konkluderede, at komiteen havde løst sin opgave med at »[...] erhverve Dybbølskanserne og sikre det danske folk disse [...]«, hvilket havde fundet tilslutning »[...] i alle lag af det danske folk.« Over alt, hvor komiteen havde søgt nye indsamlere, havde den ifølge Vagn Jacobsen mødt velvilje, og den havde fået hjælp fra pressen "[...] direkte som indirekte $[\ldots] \ll .{ }^{116}$

Når Vagn Jacobsen mente, at den danske nation ved indsamlingen havde tilsluttet sig komiteens opråb af 10. februar 1922, selvom færre end de forventede 200.000 danskere havde afgivet $1 \mathrm{kr}$., var det netop 


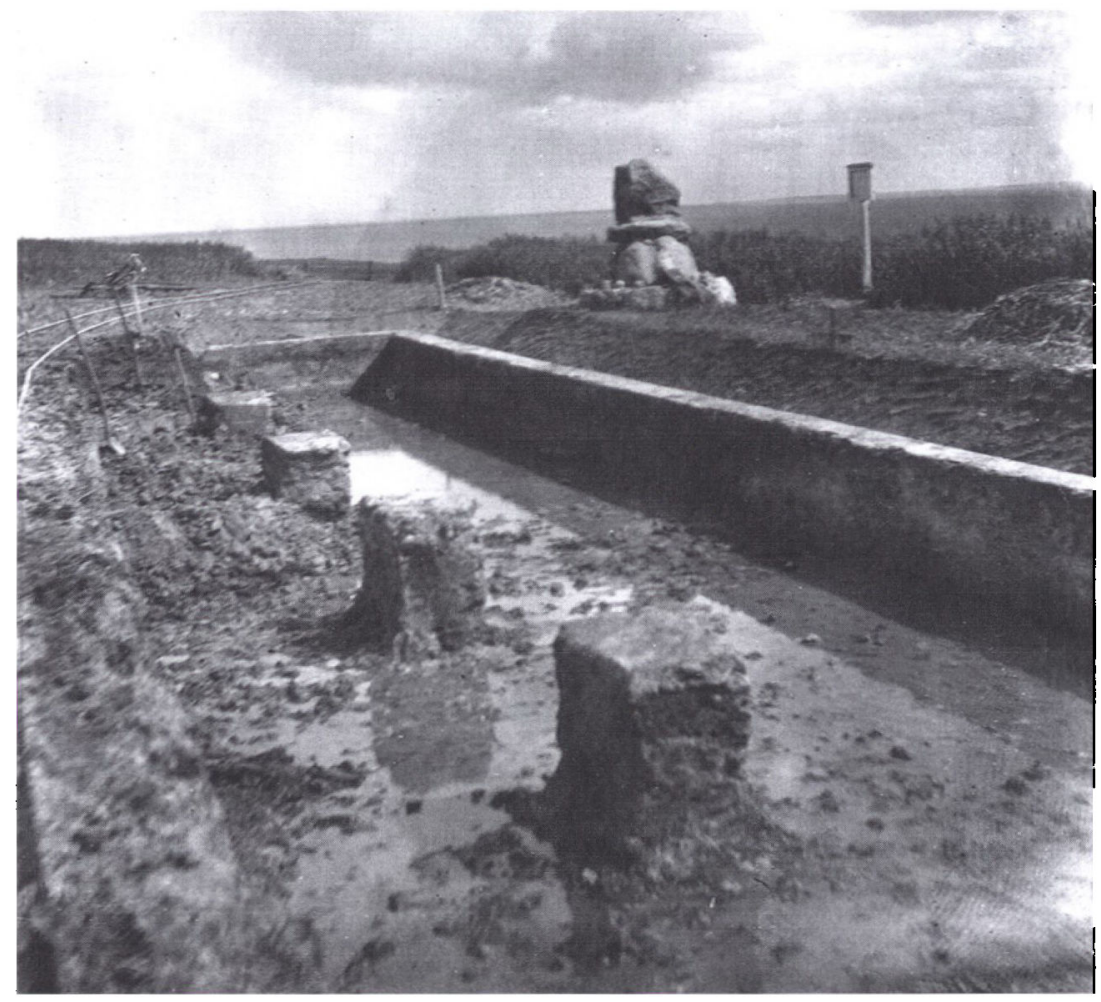

Blokhusfundamentet $i$ skanse 2 under udgravning $i$ 1923. Endnu da den preussiske stat omkring 1906 frasolgte skansearealet til gårdejer E. Lauterlein, skal konturer af skansens volde have været synlige, men efter salget blev de udjævnet. Da skansekomiteens stiftere $i 1921$ kobte E. Lauterleins gård, blev det muligt atter at markere den danske skanses beliggenhed med cementkantsten og udgravning af blokhusfundamentet og krudtmagasinresterne. Foto: Museum Sonderjylland-Sønderborg Slot.

grundet tidens økonomiske trængsler og uro på arbejdsmarkedet. Hele nationen bakkede op om komiteen og opråbet. Blot havde ikke alle kunnet støtte den kontant. Nationen havde via indsamlingen udtrykt vilje til at opbevare en kollektiv erindring om det tapre nederlag i 1864, som Genforeningen havde givet oprejsning for, og dermed iscenesat skanserne på Dybbøl som dansk erindringssted, ifølge Vagn Jacobsen.

De fremmødte komitemedlemmer tog uden videre kommentarer beretningen til efterretning og valgte Vagn Jacobsen, Chr. Gulmann, kontorchef Louw og Edv. Ehlers samt amtmand Lundbye til et arbejdsudvalg, som altså skulle udføre komiteens videre arbejde med denne opfattelse af indsamlingen $i$ bagagen. ${ }^{117}$ 
Komiteens hidtidige arbejdsudvalg havde altså opfyldt de praktiske betingelser for, at indsamlingen kunne blive en samlet nations iscenesættelse, som den selv havde indflydelse på, idet den havde skabt et net af indsamlingssteder, så de fleste danskere havde nem adgang til at aflevere en enkrone. Samtidig havde komiteen via disse indsamlingssteder og ikke mindst pressen udbredt kendskabet til indsamlingen til antageligt hele den danske nation. Derimod havde udvalget ikke haft indflydelse på den økonomiske afmatning, som begrænsede den enkelte danskers økonomiske formåen. For komiteen forekom det derfor plausibelt at hævde, at indsamlingen var et udtryk for hele den danske nations opbakning til komiteen, selvom det numerisk set kun var et mindretal af den samlede befolkning, der havde afgivet en enkrone.

Det kan da heller ikke udelukkes, at den begrænsede kontante tilslutning var et udtryk for, at kun få havde råd til at støtte indsamlingen. J.P. Nielsens og den socialdemokratiske presses kritik af indsamlingen skyldtes, at de mente, at staten skulle frede skanserne frem for en privat skansekomite. Selvom især konservative aviser og venstreblade aktivt støttede indsamlingen, var den altså ikke repræsentativ for den danske nation i politisk og social henseende. Men uenigheden gjaldt, hvilken erindringsform - staten eller privates initiativ - der skulle skabe et fælles dansk erindringsrum på Dybbøl, og ikke hvilke af de internt konkurrerende danske erindringer, der skulle opbevares der. Denne uenighed fortrængte komiteen imidlertid udadtil i pressen og opretholdt her en forestilling om indsamlingen som et udtryk for hele den danske nations støtte til dens opkøb og fredning af skanserne på Dybbøl som dansk erindringssted. Hvordan kom det fysiske erindringsrum, som skulle være hele den danske nations erindringssted om krigen i 1864, da til at se ud?

\section{Skanseprægning}

I efteråret 1922 lod arbejdsudvalget den indre omkreds af voldene, i skanserne 1-9 markere med hvide cementkantsten, ${ }^{118}$ mens blokhusfundamenterne og krudtmagasinresterne i skanse 1, 2, 6, 8 og 9 blev udgravet i 1923 og 1924 på foranledning af Museet på Sønderborg Slot. Samtidig blev skanse 1, 5 og 6's nummersten genopstillet, ${ }^{119}$ og i hver dansk skanse opstilledes et kort over denne. ${ }^{120}$

Endvidere fik udvalget i foråret 1924 op ad en høj midt i Konge- 
skansen opsat en tavle af sandsten tegnet af arkitekt Brummer med følgende tekst af Chr. Gulmann: "Genforeningen til minde blev Dybbøl skanser erhvervede ved en landsindsamling og i året 1924, den 18. april, overdragne til den danske stat som nationalpark. Denne sten står i Kongeskansen, hvor Kong Christian den tiende i året 1920, den 11. juli, modtog de trofaste danske, der vendte tilbage til fædrelandet. «121

Ved at lade tavlen minde om Genforeningen fik komiteen markeret, at skansearealerne med landsindsamlingen var blevet iscenesat som et dansk erindringssted, uden at den dog greb ind i de eksisterende tyske iscenesættelser på Dybbøl, og den udtalte sig heller ikke for eller imod et dansk militært forsvar. Komiteen havde altså skabt et fysisk erindringsrum, som hele den danske nation kunne dele som erindringsform trods internt konkurrerende erindringer ved alene at se Genforeningen i 1920 som en oprejsning for nederlaget i 1864. Udadtil gav komiteens prægning af skanserne da indtryk af en samlet kollektiv dansk erindring.

\section{Køb, salg og servitutter}

Komiteen frasolgte de arealer, som lå udenfor de danske og tyske skansearealer, $\mathrm{i}$ alt 46,7 ha. Lauterleins gård blev solgt for $82.137,30$ kr., mens de øvrige arealer blev solgt for $\mathrm{i}$ alt $28.275,82 \mathrm{kr}^{122}$ Komiteen pålagde de frasolgte arealer servitutter om, at de kun måtte anvendes til agerbrug og havebrug og ingensinde bebygges undtagen i landbrugsøjemed i max. to etager med statens tilladelse i hvert tilfælde. ${ }^{123}$ På selve skansearealerne var enhver form for byggeri forbudt, idet de skulle "[...] stedse bevares samlede i statens eje som et nationalt og historisk mindesmærke" i samme stand som ved overtagelsen. Dog var ændringer tilladt "[...] hvorved tilsigtes at markere eller fremhæve yderligere end allerede sket de gamle danske skansers beliggenhed." Endvidere skulle der $»[\ldots]$ stedse være uhindret adgang for offentligheden til hele det overdragne areal«, som i erhvervsøjemed kun måtte anvendes til græsning af ungkvæg og får. ${ }^{124}$ Servitutten på skanserne skulle altså bevare deres iscenesættelse som dansk erindringssted, der eventuelt kunne udbygges. Derimod var det ikke hensigten at tillade nye tyske iscenesættelser.

Skansearealerne skulle være under tilsyn af et nævn, Dybbøl-Skanse-Nævnet, som bestod af præsidenten for Søndre Landsret, det amts- 
rådsvalgte medlem af det lokale fredningsnævn samt et medlem valgt af og iblandt de i Sønderjylland bosiddende rigsdagsmænd. ${ }^{125}$ Amtmand Lundbye var betænkelig ved valget af det tredje medlem, idet han mente, at nævnet ikke kunne tage affære overfor en eventuel socialdemokratisk regering, hvis valget faldt på J.P. Nielsen. ${ }^{126}$ Derfor vedtoges på arbejdsudvalgets møde med komiteens repræsentant$\mathrm{skab}^{127}$ den 11. juni 1923, at komiteen selv valgte et fjerde medlem, som så valgte sin efterfølger for derved at tilvejebringe "passende kontinuation « mellem komiteen og nævnet. ${ }^{128}$ Servitutterne blev vedtaget af den samlede komite den 29. juni 1923 med den tilføjelse, at det fjerde nævnsmedlem skulle bortfalde efter at have været beklædt af tre personer. ${ }^{129}$

Komiteen overlod det altså ikke til den danske stat og de til enhver tid siddende politiske magthavere at bestemme, hvad der var i overensstemmelse med komiteens iscenesættelse af skanserne på Dybbøl som dansk erindringssted. Amtmand Lundbyes betænkeligheder antyder, at komiteen her havde et øje til det fremvoksende Socialdemokrati, hvorfra J.P. Nielsen og dets presse jo havde ytret kritik af den form for iscenesættelse, som komiteen praktiserede.

\section{Staten på nationens vegne}

Ved en audiens den 2. juli 1924 overrakte Vagn Jacobsen, Edv. Ehlers og kontorchef Louw kong Christian $\mathrm{X}$ et gavebrev, hvormed komiteen overdrog skansearealerne til staten. Landets nyudnævnte første socialdemokratiske statsminister Thorvald Stauning deltog også, og han udtalte da, at han snarest ville besøge skanserne. ${ }^{130}$

Den 11. juli 1924 vandrede Stauning da sammen med blandt andre Vagn Jacobsen og ca. 30 indbudte igennem skanse 1-9 i smukt vejr. Ved tavlen i Kongeskansen takkede Thorvald Stauning komiteen for, "[...] at disse minderige steder kan bevares som folkets ejendom." Ifølge Dybbøl-posten udtalte han, at nationalparken "[...] rummer så mange vidnesbyrd om troskab mod det land og det folk, vi elsker. Her var det, at danske soldater kæmpede for vort folks frihed i mørke og tilsyneladende trøstesløse stunder, de måtte bøje sig for overmagten og opnåede ikke at hente sejren hjem. Vi vil i dag også mindes den kamp, som blev ført hernede de følgende 56 år, en kamp for dansk åndsliv og dansk sprog. Det var en hård kamp, men de måtte igennem den inden vi nåede at se dette land genvundet. [...] Vi ønsker 
ikke at bevare mindet her for at manifestere viljen til at opretholde den form, under hvilken disse kampe her fandt sted. Vi ønsker, at de blodige krige med deres mange rædsler, må være noget, som nu og $\mathrm{i}$ fremtiden hører fortiden til, men vi vil bevare mindet om den nationale kamp, der er bleven ført her på disse steder. Dette sted står som et minde, hvoraf fremtid gror; skanserne er ligesom Dybbøl mølle vogter for et mindebo. [...] $\ll^{131}$

Stauning knyttede altså på hele det danske folks vegne en erindring til skanserne om det militære nederlag i 1864 og de dansksindede nordslesvigeres kulturelle kamp, der endte med Genforeningen i 1920, hvilket den danske nation burde bevare mindet om i eftertiden. Ifølge Stauning var krigen noget, som nationen ønskede at undgå i fremtiden, men han sagde intet om, hvordan krigen skulle undgås. Det anes her, at Stauning modsat ved grundlovsmødet i 1921 nu også var hele landets statsminister. Det var netop som statsminister og ikke som socialdemokratisk partiformand, at Thorvald Stauning modtog skanserne på nationens vegne.

Da Staunings regering var en mindretalsregering på radikale stemmer med et borgerligt flertal i Landstinget imod sig, ${ }^{132}$ og i betragtning af at disse politiske grupper havde forskellige erindringer om krigen i 1864, måtte kunsten da være at balancere i forhold til disse erindringer. Staunings tale stod ikke $i$ modsætning til nogen af de konkurrerende danske erindringer om krigen i 1864, men som socialdemokrat var han næppe heller imod, at området tilfaldt staten.

Sønderborg Amts Social-Demokrat bragte den 13. juli et fyldigt uddrag af Staunings tale uden dog at nævne, at han omtalte skanserne som en "vogter for et mindebo «. ${ }^{133}$ Derimod havde Social-Demokraten kun en notits den 12 . juli om, at statsministeren havde fået overleveret de fredede arealer, og at der var afsløret en mindesten. ${ }^{134}$ Berlingske Aftenavis bemærkede da samme aften, at Social-Demokraten nok ikke turde fortælle sine læsere, at Stauning på regeringens og folkets vegne kaldte skanserne for en »[...] vogter for et mindebo. «135 To dage senere hed det videre i Berlingske Aftenavis, at "[...] hvis hr. Staunings tale var kommet $\mathrm{i}$ "Social-Demokraten", ville Dybbøl Mølle have knejset i bladet som en skamstøtte rejst over det selv [...]", mens den danske arbejder ville føle sig "[...] på hjemlig grund, i harmoni med sin egen natur, i selskab med sine følelser og tanker«, når han hørte Staunings tale. ${ }^{136}$

Efter disse svadaer fra den konservative aftenavis trykte Social-De- 


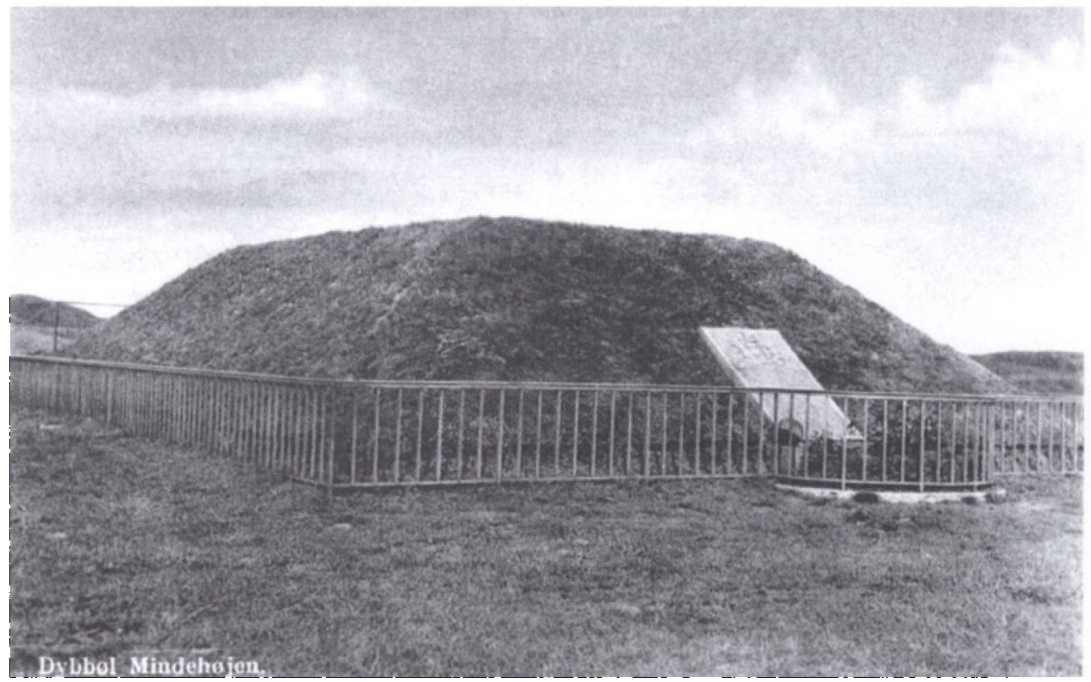

Skansekomiteen rejste i 1924 en mindetavle $i$ Kongeskansen for opkrbet af skansearealerne. Højen var oprindeligt en tværoold i den preussiske skanse X fra 1865, men med tavlen blev den til en del af skansekomiteens iscenesættelse af Dybbol Banke som et dansk erindringssted. Indhegningen er senere fjernet, men tavlens tekst giver stadig indtryk af, at komiteens indsamling var en samlet dansk nations værk, hoad den imidlertid ikke var. Foto: Museum Sonderjylland - Sonderborg Slot.

mokraten den 15. juli et større uddrag af Staunings tale, men stadig uden vendingen om skanserne som "vogter for et mindebo.« Ifølge avisen hyldede Stauning "[...] troskaben mod folk og land og fremhævede samtidig det danske folks inderlige onske om varig fred og et godt forhold til andre nationer." Selvom "Dybbel-minderne" ofte havde "[...] været udnyttet til militaristisk rummel [...]«, var Staunings tale på Dybbøl for socialdemokrater kun et naturligt udslag af regeringsskiftet, da det ikke har »[...] været nogen hemmelighed, at af de blodstrømme, der blev udgydt i ulige og håbløs kamp ved Dybbøl, har Socialdemokratiet draget den lære, at det er forbryderisk mod land og folk at lade dets skæbne bero på våbenlykke. «137

Berlingske Aftenavis svarede da, Stauning nok havde advaret imod "[...] at dyrke et sådant ideal som kampen med overmagten, vel at mærke når det drejer sig om militær kamp.« Men havde Stauning talt i 1864, havde han sikkert talt for "[...] kampen for folkets frihed; og den kamp - det er hr. Stauning selv, der siger det - kæmpede den 


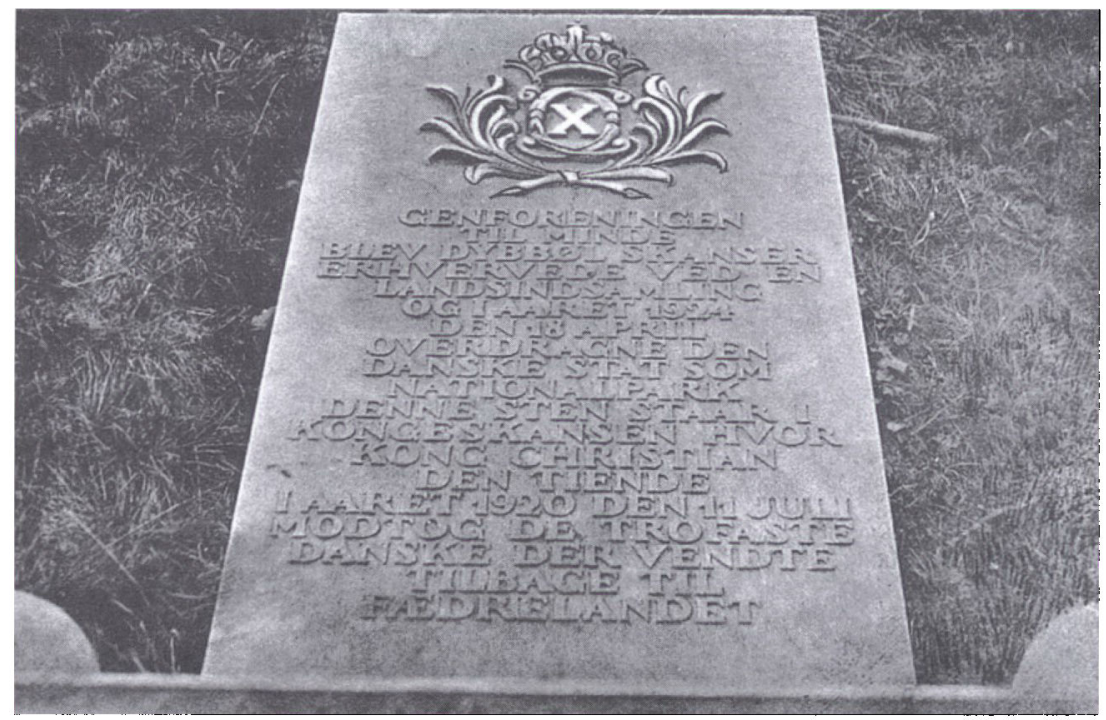

Se billedtekst på modståcnde side.

danske soldat i 1864.« Der var således ikke opbakning udenfor Socialdemokratiet til at begrænse militærets opgave til at bevare ro og orden internt $\mathrm{i}$ landet. ${ }^{138}$

Det svarede Social-Demokraten aldrig selv på, men i Fyns Social-Demokrat den 15. juli og i Sønderborg Amts Social-Demokrat den 17. juli blev Berlingske Aftenavis' kritik afvist i næsten enslydende artikler, som da også kan være bragt $\mathrm{i}$ andre socialdemokratiske blade. Det hed: "Vi har aldrig ladet hånt om vort lands historiske minder. Men vi har protesteret imod deres udnyttelse i chauvinistisk øjemed. Vi har altid næret den dybeste medfølelse med de folk, som regel vore egne klassefæller, der måtte ofre livet på valpladserne.« Når nordslesvigerne blev genforenet med Danmark i 1920, var det "[...] i kraft af det af Socialdemokratiet forfægtede nationalitetsprincip og selvbestemmelsesretten. «139

Berlingske Aftenavis og Social-Demokraten, støttet af mindst to socialdemokratiske lokalaviser, skændtes altså om, hvad der var den rette lære for den danske nation af nederlaget på Dybbøl i 1864. Berlingske Aftenavis mente, at forsvaret for nationens frihed også indebar militær kamp mod en overmagt, og at socialdemokraterne med Staunings 
tale indirekte var kommet til at anerkende dette. Det afviste de to socialdemokratiske blade, der selv om de tilsyneladende accepterede komiteens iscenesættelse af skanserne som dansk erindringssted ikke mente, at Stauning havde udtrykt et nyt synspunkt i sin tale. Læren af 1864 var stadig, at militært forsvar mod en overmagt var håbløst.

Da først det fælles erindringsrum var etableret, konkurrerede danske erindringer internt om at blive opbevaret $i$ dette nationale erindringssted. Komiteen selv havde jo ved sin prægning ikke udelukket nogen dansk erindring fra at blive knyttet til stedet. Men Socialdemokratiet indledte i starten af 1920'erne en forandring fra at være et klasseparti til en bred folkelig bevægelse, der så sig selv som en del af den danske nation på tværs af politiske og sociale skel. Ved grundlovsmødet i 1921 hæudede J.P. Nielsen, at arbejderklassen havde førsteretten til Dybbøl Banke, men ved komiteens stiftende møde året efter begrundede han sin modstand imod opkøbet og indsamlingen til skanserne med, at den var overflødig med henvisning til den verserende fredningssag jævnfør naturfredningsloven. Da Stauning modtog skanserne i 1924 på statens vegne var det netop som hele nationens statsminister og ikke som repræsentant for en bestemt politisk og social gruppe, idet han kun udtrykte håb om, at den danske nation kunne undgå krig i fremtiden uden at tage stilling til, om det skulle ske med eller uden et militært forsvar.

Omvendt blev det for borgerlige grupperinger stadig sværere at afvise den socialdemokratiske bevægelse som en del af den danske nation. Komiteen og dens støtter foregav under indsamlingen, at opkøbet af skanserne blev støttet af hele nationen. Polemikken mellem Social-Demokraten og Berlingske Aftenavis om Staunings tale i 1924 må ses som en del af denne udvikling. Som konservativ avis repræsenterede Berlingske Aftenavis en af de politiske grupper, som netop havde tabt regeringsmagten til socialdemokraterne. Aftenavisen hævdede imidlertid, at Stauning havde æret det danske militære forsvar i 1864 og dermed i virkeligheden havde antaget de borgerliges nationale fællesskab. Både borgerlige, de radikale og nu også socialdemokraterne udtrykte nu i 1924 sig selv og hinanden som en del af den danske nation, der opbevarede erindringer om nederlaget i 1864 på Dybbøl Banke. På den baggrund skal vi til slut se nærmere på eftertidens brug og udbygning af skansearealerne som et iscenesat dansk erindringssted frem til 1945. 


\section{Udbygning og brug i eftertiden}

I 1924 stiftede museumsinspektør Jens Raben, postmester M.O. Ræder og kaptajn Chr. Bokkenheuser den private Komiteen for Rejsning af Mindestene for Faldne i de slesvigske Krige, som indtil 1948 rejste $i$ alt 110 sten, hvoraf 97 var over faldne fra 1864. De 86 af stenene stod på Sundeved, især på Dybbøl Banke og skansearealerne, og de fleste angav blot de faldnes navne, regiment og dødsdato. ${ }^{140}$

De mange sten mindede om danske soldater, som havde ydet det ultimative offer for den danske nation. De gjorde skanserne til et symbol på hele den danske nations nederlag i 1864, da de fleste sten angav, at her var en soldat i den danske hær blevet dræbt i 1864. Men da mindestenene kun var rejst over danske faldne, iscenesatte de alene skanserne som et dansk erindringssted.

Samtidig blev Kongeskansen brugt til at vise dansk sammenhold indadtil som udadtil. Tiåret for Genforeningen den 15. juni $1930 \mathrm{blev}$ fejret her med taler af statsminister Thorvald Stauning og den radikale C. Th. Zahle, der begge udtrykte glæde over Genforeningen og betonede, at det tyske mindretal blev behandlet retfærdigt, mens Niels Neergaard og den konservative partileder John Christmas Moller også talte om, at forsvaret mod overmagten i 1864 var en forudsætning for Genforeningen. ${ }^{141}$ Omkring 1930 var der relativt roligt i og omkring Nordslesvig, men den manglende tyske anerkendelse af 1920-grænsen blev højaktuel kort efter Hitlers magtovertagelse i Tyskland i 1933, da slesvig-holstenske nazister udsendte verbale trusler mod det danske herredømme i Nordslesvig og talte om, at det tyske flag igen ville veje på Dybbøl. Som en reaktion herpå afholdt de sønderjyske ungdomsforeninger den 11. juni 1933 et stævne i Kongeskansen med 40.000 deltagere, hvor H.P. Hanssen talte om, at den danske nation overfor grænserevisionskravene skulle »[...] rejse et ubrydeligt bolværk! ${ }^{142}$

Det tyske mindretal blev dog stadig mere nazificeret i 1930'erne, og højrøstede $\mathrm{i}$ deres krav om en grænserevision samtidig med, at den tyske stat indledte en militær oprustning. ${ }^{143}$ Formentlig i lyset heraf blev skansernes danske iscenesættelse yderligere udbygget, da en privat komite i 1936 for egne penge rejste en 8 meter høj obelisk til minde om de frivillige $\mathrm{i}$ den danske hær $\mathrm{i}$ de slesvigske krige fra Sverige, Norge, Finland og Island. Obelisken blev placeret ved landevejens sydside ved indgangen til skanse 4, hvor den ifølge Dybbøl- 
Skanse-Nævnet ville være synlig uden at skæmme Düppel Denkmal. ${ }^{144}$ Den blev afsløret den 27 . oktober 1936 i overværelse af bl.a. lokale rigsdagsmænd, repræsentanter for de nordiske lande og 6-700 tilskuere. Thorvald Stauning talte da om, at "det danske folk vil stedse opfylde sine forpligtelser over for folkene og verden, hvis ulykkelige begivenheder skulle tvinge os dertil« ${ }^{145}$

At der blev taget hensyn til Düppel Denkmal ved obeliskens placering viser, at Tyskland blev opfattet som stadigt mere truende. Modsat stævnet i Kongeskansen i 1933 blev der nu gået diplomatisk til værks overfor den tyske nation for at undgå uro. Men med obelisken for de nordiske frivillige blev der knyttet bånd mellem samtiden i 1936 og fortiden i 1864 og dermed stadig knyttet en erindring til Dybbøl Banke om nordisk solidaritet og dansk forsvarsvilje overfor den tyske nation.

Dette gentog sig, da Fredningsnævnet for Sønderborg Amtsraadskreds efter anmodning fra Dybbøl-Skanse-Nævnet den 2. august 1939 afsagde en kendelse om fredning af området vest for skanse 3 og 4 fra Kongeskansen og 450 meter sydpå mod bebyggelse og andet, der kunne skæmme udsigten, da "[...] Dybbøl Banke og Broagerland er knyttede nøje sammen $\mathrm{i}$ den historiske bevidsthed, idet det særligt var fra Broagerland, at fjenden i 1864 med sine langtrækkende kanoner beskød skanserne på Dybbøl«146, hvilket Overfredningsnævnet stadfæstede. ${ }^{147}$

Med ordene om, at det var "fjenden «, der fra Broagerland beskød skanserne i 1864, skete fredningen entydigt ud fra en dansk erindring om krigen i 1864, men det fremgik dog ikke af det for byggeri friholdte areal, ligesom ministres og rigsdagsmænds taler ikke satte sig varige spor på Dybbøl Banke modsat de permanente udbygninger af skanserne som dansk erindringssted med mindestenene og obelisken, der ligesom skansekomiteen var private foretagender. Spillerummet hertil var fortsat storre for private end for staten, men ikke til hvad som helst.

Således vakte det lokal modstand, da skanserne blev søgt tillagt en fælles mening for både den danske og den tyske nation af arkitekt Dan Fink, havearkitekt C. Th. Sørensen og billedhugger Jens Lund, da de i juli 1940 via Danmarks Naturfredningsforening foreslog en fredning af hele Dybbøl Banke, idet "[...] skanseområdet er en national helligdom for tyske som danske [...] Mellem skanse 6, 7 og 8 skulle der anlæegges et amfiteater med plads til 6.000 personer, Konge- 


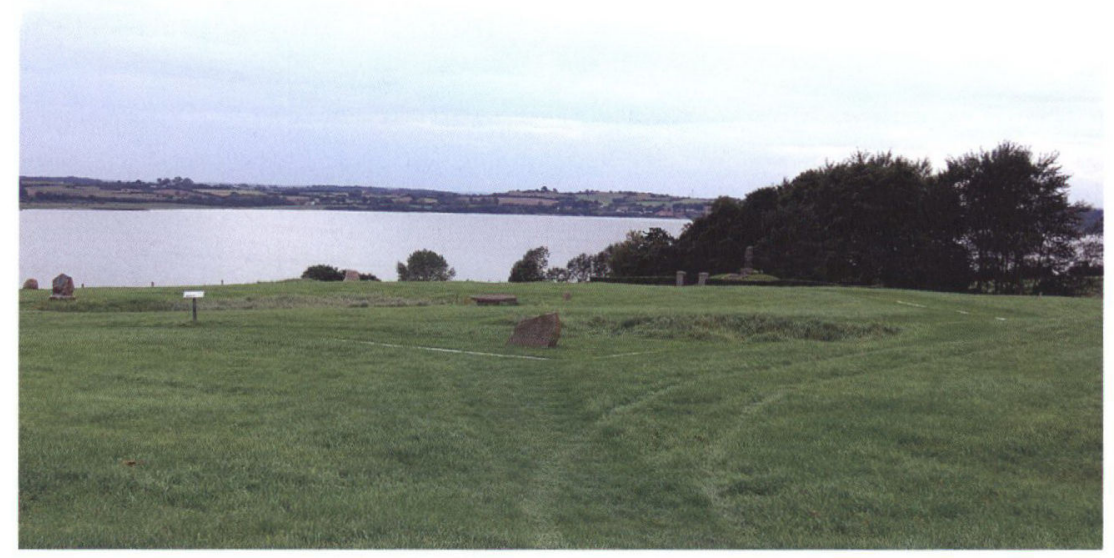

Skanse 2 i september 2008. I baggrunden th. ses det tyske monument for den preussiske pioner Klinke. I 1980'erne arbejdede et udvalg forgæues for en genopforelse af skansen. Ligesom de ovrige skansearealer er skanse 2 stadig domineret af iscenesættelsen som danske erindringssted 1922-1924. Komiteen foranledigede udgravning af krudtmagasinet, som anes $i$ forgrunden th. og blokhusfundamentet bagved tv. og markerede desuden skansens ildlinie med hvide cementkantsten i græsset og rejsning af danske mindesten. Foto: Lars Bak.

skansens rumvirkning skulle oges ved afgravninger, og i dens nordlige ende skulle der anlægges en mindeplads med en i national henseende neutral skulptur af en kvinde og en omsegnet mand. Foruden forlægning af landevejen bag om fællesgravene foresloges dog også, at skanse 1 eller 7 blev rekonstrueret. ${ }^{148}$

Blandt naturfredningsforeningens lokale komiteer i Nordslesvig vakte forslaget imidlertid kritik fra især formanden for komiteen $\mathbf{i}$ Sønderborg, postmester M.O. Ræder, støttet af museumsinspektør Jens Raben. De gik ind for en fredning af Dybbøl Banke, men »netop fordi skanseterrænet og Dybbøl Banke er en national helligdom, bør det så vidt muligt ikke røres [...]«. Da naturfredningsforeningens hovedbestyrelse ikke fandt lokal opbakning, opgav den forslaget. ${ }^{149}$

Forslaget kom imidlertid til offentlighedens kendskab i marts 1942, da Jens Lunds forslag til skulpturen blev udstillet på Den frie Udstilling i København. På et møde i Sønderborgs borgerforening fandt redaktør Chr. Refslund, Flensborg Avis, da, at området burde fredes, 
men der måtte "[...] under ingen omstændigheder finde nogen forandring sted af selve Kongeskansens karakter, der netop i sin nuværende tilstand er den smukkeste mødeplads, som tænkes kan, og helt værdig mindet om fortidens kampe og den uforglemmelige fest $\mathrm{i}$ sommeren $1920 . \ll^{150}$

Kritikerne fremførte altså, at der ikke måtte ændres i Dybbøl Bankes tilstand, som jo siden 1920 i stigende grad var blevet iscenesat og brugt som hele den danske nations erindringssted. Med den tyske besæettelse af Danmark den 9. april 1940 havde de dansksindede i Nordslesvig næppe behov for at iscenesætte skanserne som et erindringssted for både den danske og den tyske nation. Tværtimod forstærkede besættelsen behovet for at vise dansk enighed på tværs af politiske og sociale skel overfor den tyske nation, som den førnævnte i november 1940 indførte daglige flagning fra flagmasten ved Dybbøl Mølle antyder.

Aktuelle forhold i samtiden helt frem til 1945 gjorde således, at danske og tyske konkurrerende erindringer om krigen i 1864 ikke kunne samles i skanserne som et fælles erindringsrum. Det var formentlig en anti-tysk aggression ovenpå Besættelsen, da ukendte gerningsmænd den 13. maj 1945 sprængte Düppel Denkmal i luften, og dermed fjernede en væsentlig iscenesættelse af tyske erindringer. ${ }^{151}$ Samtidig lykkedes det de endnu levende medlemmer af skansekomiteens arbejdsudvalg, kontorchef Louw og amtmand Lundbye, at erhverve skanse 10 fra Chr. Kolbes arvinger. Skanse 10's beliggenhed blev markeret som på de øvrige arealer, inden den blev overdraget til den danske stat den 15. juni 1945, hvorved skansearealerne blev yderligere iscenesat som dansk erindringssted overfor den tyske nation. ${ }^{152}$ Som sådan blev arealerne atter brugt, da 25-året for Genforeningen 11. juli 1945 blev fejret i Kongeskansen af 50-60.000 mennesker. Bl.a. den socialdemokratiske statsminister Vilhelm Buhl talte da om, at det tyske mindretal trods en lempelig dansk mindretalspolitik havde krævet grænsen ændret, mens det danske mindretal syd for grænsen loyalt havde opfyldt deres pligt som tyske statsborgere og været soldater i den tyske værnemagt. ${ }^{153}$

Med folkemøderne foregik der således frem til 1945 en øget brug af skansearealerne som et dansk erindringssted overfor den tyske nation, hvori også socialdemokraterne deltog. Det var muligt, idet komiteen havde tillagt de danske erindringer en fælles mening i sin prægning af skansearealerne, som bl.a. de mange mindesten byggede vide- 
re på. Den danske nations politiske og sociale grupper brugte efter 1924 skanserne som et fælles erindringsrum til at samle deres internt konkurrerende erindringer og tillægge dem en fælles mening om Genforeningen i 1920 som en retfærdig oprejsning for nederlaget i 1864. Eftertidens brug af skanserne skabte da en forestilling om en fælles dansk erindring om krigen i 1864 som slørede, at Komiteen for Erhvervelse af Dybbøl Skanser ikke var en enig dansk nations iscenesættelse af sit erindringssted, da dens indsamling fandt sted i 1922.

\section{Konklusion}

Endnu i 1922 var Dybbøl Banke domineret af tyske iscenesættelser, og da en del af skansearealerne var i privat tysk eje og andre truet af tyske opkøb, opkøbte initiativtagerne til skansekomiteen skanserne for at hindre yderligere iscenesættelser af tyske erindringer ved at iscenesætte skansearealerne som et dansk erindringssted.

Da den danske stat førte en generelt forsigtig politik overfor den tyske stat og det tyske mindretal, og da en fredning efter naturfredningsloven ikke kunne fjerne eller hindre tyske iscenesættelser, var der større spillerum for danske iscenesættelser $\mathrm{i}$ komiteens private regi. Til gengæld havde komiteen ikke på forhånd mandat til at iscenesætte skanserne på vegne af hele den danske nation. Derfor iværksatte komiteen en indsamling for at vise, at købet af skanserne var en enig dansk nations værk på tværs af politiske og sociale skel. Udadtil tillagde komiteen da skanserne en fælles mening om Genforeningen som en retfærdig oprejsning for nederlaget i 1864 uden at tage stilling til, om et militært forsvar var nødvendigt og iscenesatte dermed én dansk erindring frem for andre internt konkurrerende danske erindringer.

Indsamlingen blev bakket op af politikere og de dele af pressen, som tilhørte de konservative, Venstre og de radikale. Derimod var der ingen opbakning fra den socialdemokratiske arbejderbevægelse, som fandt indsamlingen overflødig. Under en samtidig storlockout havde arbejderbevægelsen næppe behov for at vise sig som en del af et nationalt erindringsfællesskab på tværs af politiske og sociale skel, og med en overvægt af repræsentanter fra borgerlige kredse og de øverste sociale lag var skansekomiteen generelt ikke et repræsentativt udsnit af den danske nation. 
Men komiteen tillagde overfor eftertiden alene skanserne en erindring om Genforeningen som oprejsning for nederlaget i 1864 med sin markering af skansernes beliggenhed, ligesom de mange mindesten for faldne danske soldater i 1864, som blev rejst efter 1924, udbyggede denne fælles danske mening. Samtidig udtrykte den socialdemokratiske arbejderbevægelse sig i stigende grad som en del af den danske nation, hvilket kom til udtryk ved en række folkemøder frem til 1945 på Dybbøl Banke. Komiteen for Erhvervelse af Dybbøl Skanser var ikke en enig dansk nations iscenesættelse af sit erindringssted, da dens indsamling fandt sted i 1922. Men hurtigt derefter blev skanserne anvendt og udbygget som sådan.

\section{LITTERATUR OG KILDER}

Adriansen, Inge: Dybbøl - et dansk og et tysk nationalt symbol, Sønderjyske årbøger 1992, p. 249-290.

Adriansen, Inge: Dybbrol Mølle. Monument \& Museum, Sønderborg 1997.

Adriansen, Inge: Nationale symboler i Det Danske Rige 1830-2000 I-II, København, 2003.

Andersen, Ole: Festung Sonderburg Düppel. Den glemte tyske fæstning ved Sønderborg, Sønderborg 1993.

Andersen, Ole: Brffelkobbel 1864 . Historien om en soldatergrav, der blev et nationalt mindesmærke, Sønderborg 1996.

Anderson, Benedict: Imagined Communities. Reflections on the Origin and Spread of Nationalism, London 1989 (Reprint).

Assman, Jan: Kollektives Gedächtnis und kulturelle Identität, i Jan Assman und Tonio Hölscher (Hrg.): Kultur und Gedächtnis, Frankfurt a.M. 1988, p. 9-19.

Bak, Lars H.: Tyske sejrsmonumenter på danske hænder. Düppel Denkmal og Arnkiel Denkmal og den danske stat 1918-1950, Sønderjyske årbøger 2003, p.7-42.

Becker-Christensen, Henrik: Det tyske mindretal i Nordslesvig 1920-1932 III, Aabenraa 1990.

Boeck, Hector: Danske Mindesmærker og Krigergrave i Sonderjylland fra
Krigene 1813, 1848-50 og 1864, København 1940 .

Clausen, H.P.: Aviser som historisk kilde, i Fortid og Nutid, 1962, p. 321345.

Connerton, Paul: How Societies Remember, Cambridge 1996 (Reprint).

Dragsbo, Peter: Byplan og bebyggelse. I: Inge Adriansen og Peter Dragsbo (red.): Sonderborg i 750 år - tværsnit og perspektiver, Senderborg 2005, p. 43-86.

Dumreicher, Carl: Dybbøl Skanser. Udgivet af Komiteen til Erhvervelsen af Dybbol Skanser, Kobenhavn 1924.

Fink, Troels: Sønderjylland siden Genforeningen i 1920, København 1955.

Fink, Troels: Da Sønderjylland blev delt 1918-1920 I-III, 2. udg. Aabenraa 1979.

Fink, Troels: Båndene bandt. Forbindelsen over Kongeåen 1864-1914 I-II, Aabenraa 1999.

Generalstaben (udg.): Den dansk-tydske Krig 1864 I-III, Kjøbenhavn 18901892.

Gram-Skjoldager, Karen: Grænsen ligger fast! Det sønderjyske spørgsmål i dansk udenrigs- og indenrigspolitik 1920-1940, Aabenraa 2006.

Hansen, Aksel: Øvrighed og sognestyre 1864-1920. I: Det Lokalhistoriske Udvalg (udg.): Dybbøl Sogns Historie, Sønderborg 1976, p. 429-445. 
Hettne, Bjorn, Sverker Sörlin og Uffe Østergaard: Den globala nationalismen, Stockholm 1998.

Japsen, Gottlieb: Betragtninger over den danske bevagelse i Nordslesvig, Sønderjyske årbøger 1973, p. 6375.

Johansen, Jens: Dybbøl 1864, Kobenhavn 1942.

Johnsen, Axel: Dannevirkemænd og Ejderfolk. Den grænsepolitiske opposition i Danmark 1920-1940, Flensborg 2005.

Kretzschmer, Knud: Den sønderjydske Fond 1918-1960, Tønder 1960.

Kaarsted, Tage: Påskekrisen 1920, 2. opl. Århus 1969.

Kæstel, Hans \& Marius Storgaard: Foreningsliv, folkefester og nationale minder, i Det Lokalhistoriske Udvalg (udg.): Dybbal Sogns Historie, Sønderborg 1976, p. 491-507.

Lampe, Jens: Dybbøl Mølle. I: Det Lokalhistoriske Udvalg (udg.): Dybbøl Sogns Historie, 1976, p. 140-152.

Lidegaard, Bo: Dansk udenrigspolitiks historie. Bind 4: Overleveren, 19141945, Kobenhavn 2003.

Lundgreen-Nielsen, Flemming: Danskhed i krige og kriser 1800-1864. I: Flemming Lundgreen-Nielsen (red.): På sporet af dansk identitet, Krbenhavn 1992, p. 109-151.

Nielsen, Leif Hansen: Tinglysningsvæsnet. I: Erik Nørr \& Hans Schultz Hansen (red.): Harmonisering eller særordning. Sønderjylland som administrativ forsøgsmark efter Genforeningen, bd. 1, Aabenraa 2002, p. 259-278.

Nielsen, Viggo: Udviklingslinier inden for danske naturfredningsbestræbelser. I: Arne Norrevang, Torben J. Meyer og Mogens Rud (red.): Danmarks Natur bd. 11: Mennesket og Naturen, København 1971, p. 111128.

Nora, Pierre: Zwischen Geschichte und Gedächtnis, Berlin 1990.

Ousager, Steen: På sporet 1847-1997. Jernbanerne, DSB og samfundet bd. II: 1914-1950. Krige og fornyelse, Odense 1997.

Raben, Jens \& M. O. Ræder: Dybbøl Banke. Samlet Oversigt over Dybbøl- fredningerne. I: Erick Strickmann (red.): Dansk Naturfredning. Danmarks Naturfredningsforenings Aarskrift 1939-1940, København 1940, p. 42-59.

Rerup, Lorenz: Slesvig og Holsten efter 1830, Kobenhavn 1982.

Søllinge, Jette D. \& Niels Thomsen: De Danske Aviser 1634-1991 bd. 3, Odense 1991.

Thomsen, Niels: Dagbladskonkurrencen 1870-1970 II. Politik, journalistik og okonomi i dansk dagspresses strukturudvikling, København 1972.

Thomsen, Niels: Dagspressen i vor egen tid. I: Niels Thomsen \& Jette Søllinge: De danske aviser 1634-1991, bd. 3, Odense 1991, p. 34-117.

Thorsen, Svend: Den danske Dagspresse bd. 1, Kobenhavn 1947.

Thorsen, Svend: Delt efter anskuelser. Den politiske partidannelses forløb $i$ Sønderjylland efter genforeningen i 1920, København 1970.

Vaupell, Otto: Kampen for Sonderjylland. Krigene 1848-50 og 1864, København 1888 .

Warring, Anette: Kollektiv erindring et brugbart begreb? I: Bernard Eric Jensen, Carsten Tage Nielsen og Torben Weinreich (red.): Erindringens og glemslens politik, Roskilde 1996, p. 205-233.

Young, James E.: The Texture of Memory. Holocaust Memorials and Meaning, New Haven and London 1993.

Utrykte kilder fra Rigsarkivet.

Statsministeriet (SM), journalsager: 112/1922, 322/1936, Justitsministeriet, 1. kontor, journalsag X8050, Overfredningsnavnet, journalsager: 34 / 21, 396/39 (RA).

Utrykte kilder fra Landsarkivet i Aabenraa.

Kreis Sonderburg, Landrådens Arkiv: 418: Den Schutz des Düppel Denkmals, Anlage und Unterhaltung eines neuen Weges, 1908-1917, Arkivet for Komiteen for Erhvervelse af Dybbøl Skanser, Dybbøl-Skanse-Nævnet (DSN), Den sønderjydske Fond (DsF) og Fredningsnævnet for Sønderborg Amtsraadskreds (LAA).

Desuden utrykte kilder fra Museet på Sønderborg Slot, Det historiske arkiv (MSS). 


\section{NOTER}

1. Adriansen, 2003 II, p. 246f. Johansen, 1942, p. 9ff. Generalstaben I, 1890, p. $75 \mathrm{ff}, \mathrm{p} .86 \mathrm{ff}$.

2. Generalstaben I, 1890, p. 302, II 1891, p. 132ff., p. 293ff., p. 312ff.

3. Generalstaben II, 1891, p. 384f., p. 391432, III 1892, p. 200-254. De danske styrketal den 18. april er eksklusive officerer og befalingsmænd.

4. Adriansen, 2003 Il, p. 258, p. 262ff., p. 268.

5. Om teorierne om erindring og erindringssteder, som ligger til grund for artiklen her, se Nora, 1990; Young, 1993; Assman, 1988; Warring, 1996; Anderson, 1989; Hettne m.fl., 1998; Connerton, 1996. Inspirationen til begrebet iscenesættelse af et erindringssted skylder jeg lektor Niels Kayser Nielsen, Institut for Historie og Områdestudier, Aarhus Universitet.

6. Adriansen, 2003 II, p. 257ff. Hettne m.fl., 1998, p. 287.

7. Adriansen, 1992, p. 257f., p. $265 f f$.

8. Adriansen, 2003 II, p. $258 f$., p. 339.

9. Vaupell, 1888, Forord. Johansen, 1942, p. 5f. Generalstaben III, 1892, p. 350.

10. Christiansen, 1992, p. 165, p. 172.

11. Bagge, 1992, p. 447f, p. 459f. Christiansen, 1992, p. 173ff.

12. Christiansen, Dansk Identitetshist., 1992 , p. 525, p. 547, p. 564 f.

13. Efter Adriansen, 1997, p. 14 og 2003 II, p. 261. Lampe, 1976, p. 147.

14. Bak, 2003, p. 8ff. Adriansen, 2003 II, p. $261 f$.

15. Hansen, 1976, p. 443 ff.

16. Nielsen, 1971, p. 114. Dragsbo, 2005, p. 58.

17. Efter Love og Anordninger 1917 A, p. $444 \S 1$, p. $446 \S 5$.

18. Jf. Nielsen, 1971, p. 114ff. Om servitutter se Berlin, 1926, p. $282 f$.

19. Se side 62.

20. Blokhus: Hus af svært tømmer midt $i$ skansen til dækning for dens mandskab.

21. Andersen, 1993, p. 15f. Raben \& Ræder, 1940, p. 46. LAA: Komiteen, pk. 2, læg 13: skr. 5. okt. 1923 fra museets inspektør Raben. MSS: L. 29. 1: Jydske T. 23. febr. 1938: Udtalelse af Raben.
22. MSS: Raben, nr. $4,7,9,12,14,15,23,47$, $48,49,96,99,106,110$. Boeck, 1940, p. 113-121.

23. MSS: Raben, nr. 13, 20, 23, 37, 51, 62,79, 87, 93, 108. Adriansen II, 2003, p. 255f.

24. Se eks. Adriansen II, 2003, p. $260 \mathrm{ff}$. Dybbol-Posten 18. april 1912 og 1913.

25. Bak, 2003, p. 8 ff.

26. LAA: Kreis Sonderburg 418: skr. 1. juli 1907. Amtsblatt 5. okt. 1907. SM 112/ 1922: Liste over overdragne statsejendomme 18. juni 1920.

27. Adriansen II, 2003, p. 258ff. Lampe, 1976, p. 147, p. 150.

28. Hele afsnittet bygger på Bak, 2003, p. 13-26.

29. Ibid.

30. Adriansen, 1997, p. 14. MSS: Raben nr. 28 og 81 .

31. Lampe, 1976, p. 147f., p. 151. Kæstel \& Storgaard, 1976, p. 505. Adriansen, 2003 I, p. $136 f$.

32. Dybbøl-Posten 18, april 1921.

33. Dybbal-Posten 21. april 1921.

34. Dybbøl-Posten 6. juni 1921.

35. Sonderjyllands Social-Demokrat 8. juni 1921 (begge citater).

36. RA: Overfredningsnævnet 34/21: skr. 9. juli 1920. Fællesudvalget repræsenterede Udvalget for Naturfredning, Foreningen for Naturfredning (fra 1924 Danmarks Naturfredningsforening), Foreningen til Hovedstadens Forskønnelse, Foreningen til Gamle Bygningers Bevaring og Den Danske Turistforening.

37. LAA: Fredningsnævnet, Forhandlingsprotokol 7. marts 1922.

38. RA: Overfredningsnævnet 34/21: skr. 25., 27. marts, 4., 8. april 1922.

39. MSS: L. 25. 4/1: Udskrift af nævnets kendelsesprotokol 28. juni 1923.

40. Kretschmer, 1960, p. 23f., p. 35, p. 39, p. $52 \mathrm{f}$.

41. LAA: Komiteen, pk. 2, læg 11: Skr. til Miang 14. juni, svar 14. juli 1921.

42. LAA: Komiteen, pk. 2, læg 11: Kobekontrakt 24. okt. 1921. Pk. 3, læg 37: Erklæring fra Berthelsen 10. apr. 1922. Pk. 3, lag 40: skr. fra Lundbye 25. aug. 1921. Pk. 6, læg: Anvisninger til Lundbye: skr. 18. okt. 1921. 
43. LAA: DsF 167: Notater + skr. 3. nov. 1921.

44. LAA: Komiteen, pk. 3, læg 40: skr. 17. dec. 1921.

45. LAA: Komiteen, pk. 3, læg 40: Telegrammer 22., 23., 24. dec. 1921. DsF 167: Telegram 27. dec. 1921.

46. LAA: DsF 167: Udskrift af bestyrelsesmøde 27. dec. 1921.

47. LAA: Komiteen, pk. 2, læg 23: Notater 4., 23. jan. 1922. Pk. 3, læg 40: skr. fra Lundbye 17. dec., telegrammer 22., 23., 24. dec. 1921. Pk. 5, skr. 20. okt., 24. nov. 1922. Dybbol-Posten 3., 9. jan. 1922.

48. LAA: Komiteen, pk. 6: Rekonstrueret regnskab for køb og salg af arealer af 6 . august 1925 udarbejdet af revisor Carl Andersen pga. manglende bilag hos amtmand Lundbye, p. 2, p. 5 og p. 8.

49. LAA: Komiteen: Vagn Jacobsens udtalelse faldt på et møde 20. juni 1922 mellem komiteens arbejdsudvalg og Komiteen for Nationalmindesmærket for Krigene 1848-50 samt 1864, pk. 4, læg 56, men Gulmann synes at omtale kongens holdning på initiativtagernes møde 23. jan. 1922, pk. 2, læg 23.

50. LAA: Komiteen, pk. 2, læg 23: Notater 23. jan. 1922.

51. LAA: Komiteen, pk. 1, læg 1: Udkast I.

52. LAA: Komiteen, pk. 1, læg 3: Liste over indbudte. Pk. 2, læg 23: skr. 30. jan.

53. LAA: Komiteen, pk. 1, læg 3: Div. afbud. Pk. 2, læg 23: Vagn Jacobsens forelæggelsestale.

54. Ibid., pk. 2, læg 23: Notater 6. febr. 1922.

55. Gram-Skjoldager, 2006, p. $131 \mathrm{ff}$.

56. Ibid., pk. 1, læg 1: Ændringsforslag + Udsendt opråb. Pk. 2, læg 23: Notater 6. febr. 1922.

57. LAA: Komiteen, pk. 1, læg 1: Udsendt opråb, læg 3: Tilslutning fra O. D. Schack 6. febr. 1922.

58. LAA: Komiteen, pk. 2, læg 23: Div. notater, særligt 10. febr., 7. juli 1922.

59. LAA: Komiteen, pk. 4, læg 55: Skr. 7., 9. febr. + udat. notat 1922 .

60. Statistisk Aarbog 1923, tabel 138.

61. LAA: Komiteen, Pk. 3, læg 49: Svar fra div. provinsblade, Pk. 1, læg 7: skr. 28. febr. 1922 + liste over blade, der modtog et reliefkort. Pk. 4, læg 55: Div. indtægtsbilag. Pk. 5: skr. 9. marts 1922.

62. Thomsen, 1991, p. 61.
63. De gennemgåede aviser er: Berlingske Tidende, Nationaltidende, Politiken, Social-Demokraten, Dybbol-Posten, Flensborg Avis, Hejmdal, Sonderburger Zeitung, Sønderborg Amts Social-Demokrat, Fyns Social-Demokrat, Fyns Stiftstidende, Fyns Tidende, Fyns Venstreblad, Odense Avis.

64. Fyns Stiftstidende 10. febr. 1922.

65. Dybbol-Posten 10. febr. 1922.

66. Fyns Tidende 10. febr. 1922.

67. Ibid. 23. marts 1922. Lister 17. febr-24. april 1922.

68. Fyns Venstreblad 8., 11. febr., 1. april 1922.

69. Politiken 9., 10. (opråbet) febr., 8. marts 1922.

70. Social-Demokraten 10. febr. 1922.

71. Fyns Social-Dentokrat 8. febr., 21. marts 1922. Sonderborg Amts Social-Demokrat, 9. febr., 21. marts 1922.

72. Sonderburger Zeitung. 8. febr., 15. april 1922. Dybbol-Posten 11. april 1922.

73. LAA: Komiteen, pk. 3, læg 40: skr. 10. febr. 1922. Blev den 11. febr. trykt i bl.a. Berlingske Tidende, Nationaltidende, Ekstrabladet og Dybbol-Posten samt 15. febr. i Fyns Stiftstidende.

74. LAA: Komiteen, pk. 1, læg 7: skr. 28. febr., 9. marts + liste 1922.

75. LAA, Komiteen, pk. 2, læg 23: Notat 13. febr. 1922.

76. LAA: Komiteen, pk. 1, læg 4: skr. 25. febr. 1922. Her og i det følgende: Pk. 1, læg 5: Udtalelser fra Petrus Beyer, J.C. Christensen, N. V. Dorph. Edv. Ehlers, P. Grau, Betty Hennings, Fr. Hiort-Lorenzen, Kai Hoffmann, Harald Ostenfeld, H. P. Prior, V. Pürchsel, O. Ricard, Helge Rode, Hermann Trier og Ellis Wolf.

77. Ibid.

78. LAA: Komiteen, pk. 5: Skr. til div. redaktioner 9., 13., 16., 20. og 24. marts 1922.

79. Opgørelsen bygger på gennemgange af de næunte blade 7 . febr.-18. april 1922.

80. LAA: Komiteen pk. 3, læg 40: Pressemeddelelse 4. marts 1922. Refereret el. gengivet i f.eks. Politiken og Nationaltidende 5. marts, Flensborg Avis og Fyns Stiftstidende 6. marts, Hejmdal 8. marts 1922.

81. LAA: Komiteen, pk. 5: Pressemedde- 
lelse 7. april 1922. Refereret el. gengivet $\mathrm{i}$ bl.a. Berlingske Tidende og Fyns Stiftstidende 8. april, Fyns Venstreblad 9. april og Nationaltidende (morgen) 10. april 1922.

82. Johansen, 1985, p. 107. Indbyggertallet for $1921 \mathrm{er}$ inkl. Nordslesvig. I alt var 1.857.000 indbyggere bosat $i$ sognekommunerne.

83. LAA: Komiteen, pk. 2, læg 23: Notater 11., 13., 18. febr., referat 7. juli 1922. Pk. 3, læg 40: skr. 21. febr., skr. til pressen 4. marts 1922.

84. LAA: Komiteen, pk. 3, læg 40: skr. 21. febr. 1922. Pk. 4, læg 51: Udateret instruktion til banker. Nationaltidende (morgen) 21. febr. 1922.

85. LAA: Komiteen, pk. 3, læg 31: skr. 18. febr. 1922. Pk. 4, læg 51: Udateret skr. til sognerådsformænd. Pk. 2, læg 23: Beretning til komiteen 7. juli 1922. Kretzschmer, 1960, p. 23. Lister eller skr. med tilslutning fra lokalkomiteerne ses ikke i skansekomiteens arkiv, mens der kun ses indbetaling af bidrag fra 40 sognerådsformænd. Tallene for tilslutning stammer alene fra Vagn Jacobsens beretning til komiteen 7 . juli 1922.

86. LAA: Komiteen, pk. 7, læg: Sogneraadsformænd.

87. LAA: Komiteen, pk. 7, læg: Nej: Div. afslag, 21. (sognefogeden) og 22. febr. (Linnet) 1922.

88. LAA: Komiteen, pk. 3, leg 40: skr. 4. marts 1922. Pk. 2, læg 23: Notater 13. febr., 3. marts 1922. Når komiteen kun næunte 150 komiteer den 4 . marts kan det skyldes, at den endnu ikke havde fået svar fra alle fondens komiteer, idet der efter notaterne fra arbejdsudvalgets mode dagen for kun havde meldt sig 140 komiteer til at samle ind.

89. LAA: Komiteen, pk. 6: Læg med div. indtægtsbilag: skr. 6. maj 1922. Pk. 7: Læg med bidrag indsendt uden opfordring.

90. LAA: Komiteen, pk. 3, læg 40: skr. 4. marts 1922. Pk. 2, læg 23: Kvittering.

91. LAA: Komiteen, pk. 6, læg: Forskellige indtægtsbilag: skr. 20. april 1922. Pk. 7, læg: Sognerådsformænd: 19., 20., 21. april, 3. maj 1922, læg: Nej: skr. 9., 14. marts, 3., 7., 10. april 1922.

92. Berlingske Tidende 11. marts 1922.
93. LAA: Komiteen, pk. 4, læg 50: skr. 4 ., 10., 11. april 1922 + udateret opråb.

94. Ibid.: Liste med indkomne bidrag fra skoleindsamlingen. Hertil kommer skoler, som indsendte bidrag på egen hånd. F.eks. sendte Statsskolen i Sønderborg 107,63 kr., pk. 7, læg Banker \& sparekasser: skr. 1. maj fra Folkebanken for Als og Sundeved. Se også Berlingske Tidende 12. april 1922: Indsamlingsliste med Rysensteens Gymnasium, Johannesskolen og Haderslevsgades Skole, Kbh.

95. Henriksen, 1980, p. 375f. Nissen, 2004, p. $52 \mathrm{f}$.

96. Jf. Statistisk Aarbog 1924, Tabel 131 underviste stats-, privat- og kommuneskolerne i København, Frederiksberg og Gentofte i gennemsnit 458, i provinsbyerne 278 og på landet 74 born.

97. LAA: Komiteen, pk. 4, læg 50: Liste med indkomne bidrag fra skoleindsamlingen.

98. Ibid.: skr. fra skoler 24., 25., 26. april, 1. maj 1922.

99. Hettne m.fl., 1998, p. $169 \mathrm{ff}$.

100. LAA: Komiteen, pk. 3, læg 47: skr. ml. Stoumann og Gulmann 10., 16., 19. febr., 1. marts 1922.

101. Ibid.: skr. 2. april fra Stoumann til Gulmann + opråb.

102. Ibid.: Udat. opråb. Pk. 7, læg: Stationsforstandere: Div. svar 2.-10. april, skr. fra Stoumann 18. april 1922. Jf. Ousager, 1997, p. 164.

103. Jf. Ousager, 1997, p. $155 \mathrm{ff}$.

104. LAA: Komiteen: pk. 7, læg: Stationsforstandere, Indsendelse af bidrag, skr. 19., 20. april, 4. maj 1922 samt skr. 17. maj 1922 fra Stoumann til komiteen med vurdering af indsamlingen.

105. Nationaltidende 1. (aften), 8. (morgen) april 1922. Politiken 5., 8. april 1922. LAA: Komiteen, pk. 2, læg 23: Referat 7. juli 1922: Vagn Jacobsens redegørelse for indsamlingen.

106. Berlingske Tidende 12., 19. april 1922.

107. Jensen, 1992, p. 194.

108. Kretzschmer, 1960, p. 36.

109. LAA: Komiteen, pk. 3, læg 46: skr. vedr. koret 4., 30. maj, 17. juni, 23. sept. 1922, 16. jan. 1923.

110. LAA: Komiteen, pk. 3, læg 45: Udateret aftale 1922. Pk. 2, læg 23: Notater 29. marts 1922 . 
111. Johnsen, 2005, p. 70.

112. LAA: Komiteen, pk. 4, læg 54: Mindesmærkekomiteens opråb. Læg 56: Indsamlingsbøger I-II 1912-15, referat 20. juni 1922.

113. LAA: Komiteen, pk. 2, læg 23: Notater 1. dec. 1921, 23. jan. 1922, referat 20. juni 1922.

114. LAA: Komiteen, pk. 2, læg 23: Referat med redegorelse af Vagn Jacobsen 7. juli 1922, p. 2 ff.

115. Ibid.p. 4 f.

116. Ibid. p. 2, p. 5, p. 13.

117. Ibid. p. 9ff. Uvist hvorfor omtales fra 1923 kun et forretningsudvalg i komiteens referater, hvis medlemmer dog var identiske med arbejdsudvalget. Derfor anvendes kun betegnelsen arbejdsudvalg i det folgende.

118. LAA: Komiteen, pk. 2, læg 23: Referat af komitemade 29. juni 1923. Læg 10: skr. 3. jan. 1923.

119. LAA: Komiteen, pk. 2, læg 13: skr. 18. april, 4. maj, 20. juli $1923 \mathrm{ml}$. Lundbye, Louw og Vagn J. Skr. 5. okt., 29. nov., 7., 9., 10. dec. 1923, 5., 8. jan. 1924 + udat. notat. Lag 23: Referater 13. dec. 1923, 9. april 1924.

120. Ibid., pk. 3, læg 32: Beretning om komiteens arbejder i omrădet okt. 1923.

121. Ibid., pk. 2, læg 23: Referat 30. jan. 1924. Dumreicher, 1924, p. 9 (originale fremhævelser).

122. LAA: Komiteen, pk. 3, læg 41: Købekontrakt 1. okt. 1922. Pk.6, regnskab p. 2, p. 5 .

123. Ibid., pk. 2, læg 22: Div. skr. 28. okt. 1922 - 20. juni $1923 \mathrm{ml}$. nævnte parter. Læg 23: referat 29. juni 1923 med forslag II og III.

124. Ibid. pk. 2, læg 23: 29. juni 1923: Forslag I.

125. Ibid.

126. LAA: Komiteen, pk. 2, læg 22: skr. 14., 19. marts $1923 \mathrm{ml}$. Louw og Lundbye.

127. Repræsentantskabet bestod af arbejdsudvalget undtagen Lundbye samt Jacob Appel, Andreas Buntzen, J.C. Christensen, Ejner Guildal, Niels Neergaard og Harald Witzansky. Det ses ikke af komiteens arkiv, hvornår representantskabet blev valgt. Det ses kun indkaldt til mødet 11. juni 1923.

128. LAA: Komiteen, pk. 2, læg 23: Referat 11. juni 1923.

129. Ibid.: Referat 29. juni 1923.

130. Ibid., pk. 2, læg 33: Pressemeddelelse udsendt af komiteen 2. juli 1924.

131. Efter Dybbol-Posten 12. juli 1924. Se også. Sønderborg Amts Social-Demokrat 13. juli 1924.

132. Christiansen, 1988, p. $193 \mathrm{ff}$.

133. Sonderborg Amts Social-Demokrat 13. juli 1924.

134. Social-Demokraten 12. juli 1924.

135. Berlingske Aftenavis 12. juli 1924.

136. Berlingske Aftenavis 14. juli 1924.

137. Social-Demokraten 15. juli 1924.

138. Berlingske Aftenavis 15. juli 1924.

139. Efter Senderborg Amts Social-Demokrat 17. juli 1924. Fyns Social-Denokrat 15. juli 1924.

140. MSS: L. 29. 1: Opråb 1. febr. 1924, Udat. beretning om komiteen, skr. 10. juni 1925, 6. febr. 1948 LAA: DSN pk. 873, læg 21: Skitse 14. febr. 1924.

141. Hejmdal 16. juni 1930.

142. Gram-Skjoldager, 2006, p. 57. Hejmdal 12. juni 1933.

143. Fink, 1955, p. 101ff. Lidegaard, 2003, p. $291 f f$.

144. RA: SM 322/1936: Skr. 22. febr., 22. aug., 16. okt. 1935, 30. aug. 1936.

145. Hejmdal 28. oktober 1936 (alle citater).

146. LAA: Fredningsnævn, Forhandlingsprotokol: Kendelse 2. aug. 1939.

147. RA: Overfredningsnævnet 396/39: Udkast til kendelse 7. nov. 1939. Raben \& Ræder, 1940, p. 51.

148. MSS: L. 25. 4-3: Forslag juli 1940.

149. lbid. Skr. Fra M. O. Ræder, Raben m.fl. til Danmarks Naturfredningsforening dec. 1940, skr. 9. marts 1942 fra Danmarks Naturfredningsforening til Rader.

150. Ibid.: Fl. Azis 11. marts, 3. juni 1942.

151. Bak, 2003, p. $28 f$.

152. LAA: DSN pk. 867, læg 3: Gavebrev 15. juni 1945. Pk. 872, læg 20: Pressemeddelelse 15. juni 1945.

153. Sønderjyden 12. juli 1945. 